\title{
Pedagogical Thoughts on Album des Six: a piano set by Les Six to represent French Nationalism
}

\author{
Dipendra Sunam \\ West Virginia University, disunam@mix.wvu.edu
}

Follow this and additional works at: https://researchrepository.wvu.edu/etd

Part of the Music Pedagogy Commons, Music Performance Commons, and the Other Music

\section{Commons}

\section{Recommended Citation}

Sunam, Dipendra, "Pedagogical Thoughts on Album des Six: a piano set by Les Six to represent French Nationalism" (2019). Graduate Theses, Dissertations, and Problem Reports. 3775.

https://researchrepository.wvu.edu/etd/3775

This Dissertation is protected by copyright and/or related rights. It has been brought to you by the The Research Repository @ WVU with permission from the rights-holder(s). You are free to use this Dissertation in any way that is permitted by the copyright and related rights legislation that applies to your use. For other uses you must obtain permission from the rights-holder(s) directly, unless additional rights are indicated by a Creative Commons license in the record and/ or on the work itself. This Dissertation has been accepted for inclusion in WVU Graduate Theses, Dissertations, and Problem Reports collection by an authorized administrator of The Research Repository @ WVU.

For more information, please contact researchrepository@mail.wvu.edu. 


\title{
Pedagogical Thoughts on Album des Six: a piano set by Les Six to represent French Nationalism
}

\author{
Dipendra Sunam \\ Research Document submitted to the \\ College of Creative Arts \\ at West Virginia University \\ in partial fulfillment of the requirements \\ for the degree of \\ Doctor of Musical Arts \\ in \\ Piano Performance \\ Peter Amstutz, DMA, Committee Chair \\ Andrew Kohn, Ph.D, Research Adviser \\ James Miltenberger, DMA \\ William Haller, DMA \\ Bernard Schultz, Ph.D
}

\author{
School of Music \\ Morgantown, West Virginia \\ 2019
}

Keywords: Piano, Piano Pedagogy, Les Six, Album des Six, Auric, Milhaud, Honegger, Poulenc, Tailleferre, Durey.

Copyright 2019 Dipendra Sunam 


\author{
ABSTRACT \\ Pedagogical Thoughts on Album des Six: a piano set by Les Six \\ to represent French Nationalism \\ Dipendra Sunam
}

Les Six, formally established in 1920, included a group of young French composers: Georges Auric (1899-1983), Louis Durey (1888-1979), Arthur Honegger (1892-1955), Darius Milhaud (1892-1974), Francis Poulenc (1899-1963) and Germaine Tailleferre (1892-1983). The primary motivation for their formation was the reaction against foreign influences, especially German Romantic music, in French music. Jean Cocteau, inspired by Erik Satie's style, proposed a new French musical aesthetic: simplicity, directness, clarity, and terseness. Les Six followed these ideals in their formative years. Their artistic association was short-lived, but while it lasted it produced Album des Six, their sole joint production, a published six-piece piano set, in 1920. The works in the Album were primarily composed as independent pieces between 1914 and 1920, and were deliberately assembled to symbolize Les Six as a coherent group in 1920. However, the group was never cohesive. Durey's refusal to contribute music for Les mariés de la tour Eiffel, Cocteau's ballet, in 1921 began the disintegration of their association.

This treatise examines Album des Six from a pedagogical perspective. Album des Six not only demonstrates the youthful styles of the composers, but also offers an engaging and effective pedagogical work. While furthering a Cocteau-Satie vision of nationalism, this set also reflects its composers' appreciation of the achievement of other then prominent Parisian composers such as Debussy and Stravinsky. This variety of influences demonstrates the richness of this concise collection.

The central component of this treatise is the discussion of Album des Six in chapter 3. In order to establish the groundwork for the discussion, this treatise briefly synthesizes the following components: Erik Satie and his piano works; Parisian cultural atmosphere; the Cocteau-Satie association and Cocteau's manifesto. The treatise concludes by highlighting important elements of the Satie-Cocteau aesthetics in the Album. 
$\underline{\text { Dedicated to my parents }}$

Bijay Kumar Sunam (1944-2015)

Bina Sunam (1950-1989) 


\section{ACKNOWLEDGMENTS}

A huge thank you to my teacher and committee chair, Dr. Peter Amstutz, who has been an incredible mentor during my time at West Virginia University.

I would like to express my sincere thanks to Dr. Andrew Kohn, my research advisor, for his advice, guidance, patience, encouragement, and support throughout this process. I greatly appreciate your time and wisdom.

Thanks also to my committee members Dr. James Miltenberger, Dr. William Haller and Dr. Bernard Schultz.

I would like to take this opportunity to thank my alma mater, Berea College. Without Berea's unique mission and generosity, I would not be here today.

I would also like to thank several people who have embarked on this educational journey with me. Thanks to my family and friends for their continued support. A special thank you to my brother and sister, Sanjay Sunam and Jyoti Baiju, as well as my brother-in-law, Ramesh Baiju. Thanks to my former piano teachers, Dr. Mell Carey, Prof. Robert Lewis, Dr. Frank Scott and Dr. Gert Wegner whose guidance has led me this far. And finally, I would like to thank Abigail Watson, my girlfriend and best friend, for her support, generosity, kindness and love. I am grateful for your presence in my life. 


\section{TABLE OF CONTENTS}

List of Musical Examples............................................................ vi

Chapter One: Introduction, Scope and Limitation...................................

Chapter Two: Background and Related Literature ................................. 8

Chapter Three: Pedagogical Thoughts................................................ 18

I. Prélude (1919): Georges Auric.......................................... 20

II. "Romance Sans Paroles" (1919): Louis Durey...............................26

III. Sarabande (1920): Aurther Honegger........................................ 34

IV. Mazurka (1914): Darius Milhaud...................................... 38

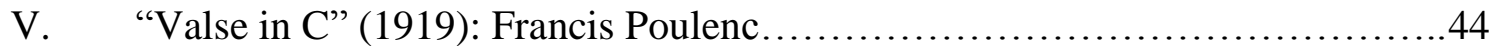

VI. Pastorale (1919): Germaine Tailleferre....................................50

Chapter Four: Conclusion........................................................ 57

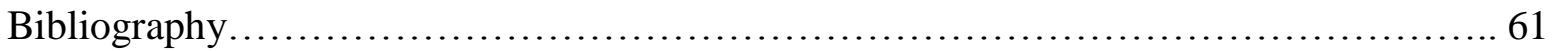




\section{List of Musical Examples}

Chapter Two: Background and Related Literature

Figure $1 \quad$ Erik Satie: Gymnopédie \#1, mm. 1-13............................10

Figure 2 Satie: Embryons desseches - "d'Edriophthalma," opening........... 11

\section{Chapter Three: Pedagogical Thoughts}

Prélude: Georges Auric

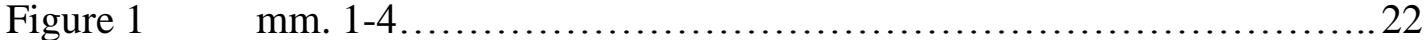

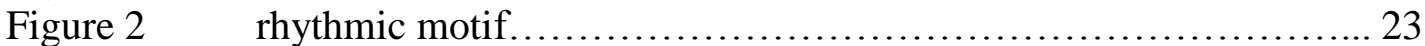

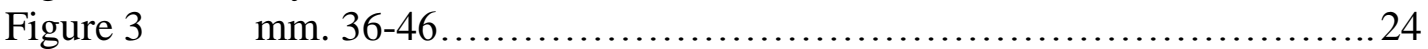

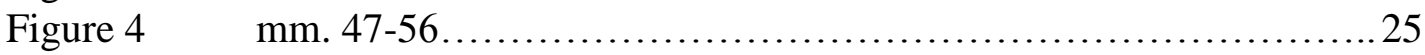

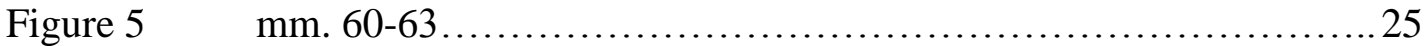

"Romance sans Paroles": Louis Durey

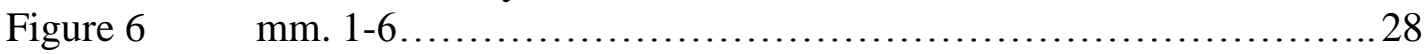

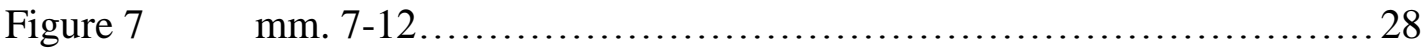

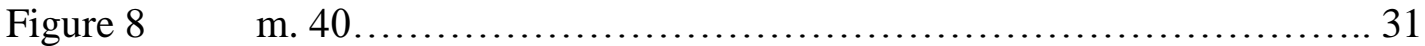

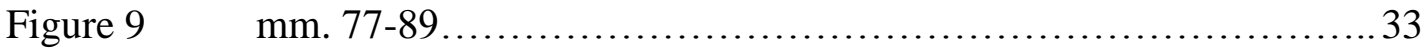

Sarabande: Arthur Honegger

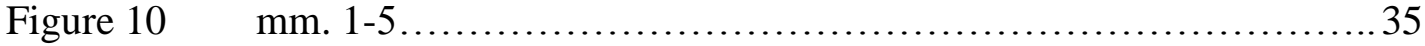

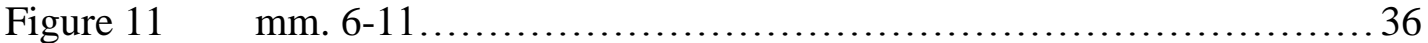

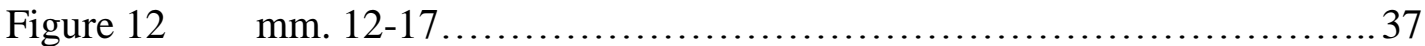

Mazurka: Darius Milhaud

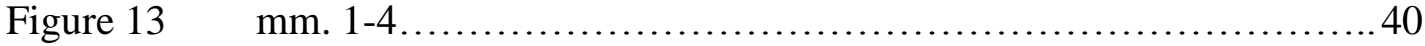

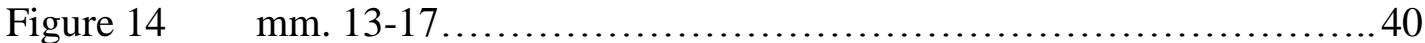

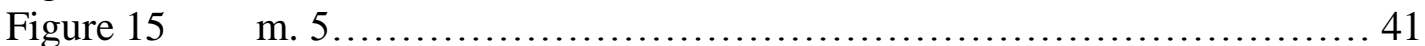

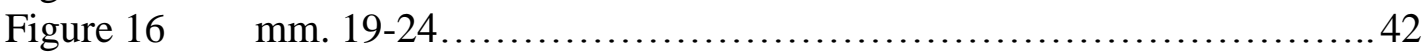

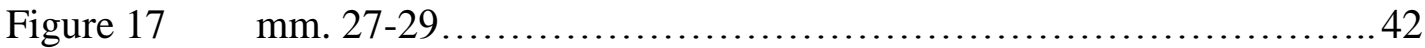

Figure $18 \quad$ m. 35 (Renotated).............................................. 43

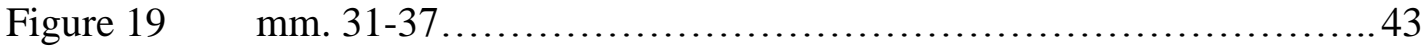

"Valse in C": Francis Poulenc

Figure 20

Figure 21

Figure 22

Figure 23

Figure 24

Figure 25

Figure 26

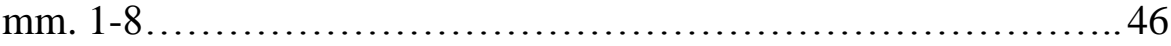

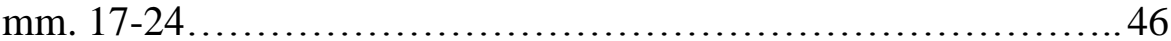

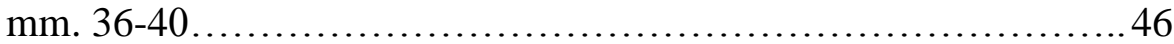

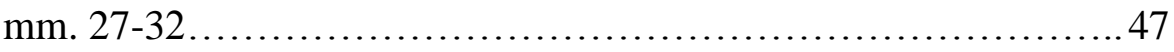

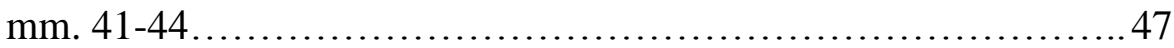

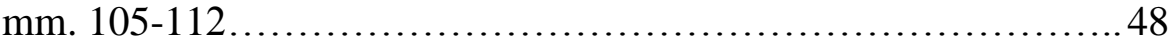

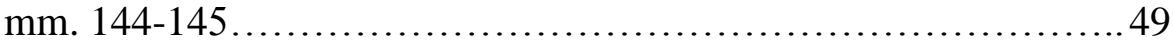




\begin{tabular}{|c|c|c|}
\hline \multicolumn{3}{|c|}{ Pastorale: Germaine Tailleferre } \\
\hline Figure 27 & mm. $1-8$ & .52 \\
\hline Figure 28 & mm. 9-14.. & .53 \\
\hline Figure 29 & mm. 20-28 & .54 \\
\hline Figure 30 & mm. 29-34 & .54 \\
\hline Figure 31 & mm. 48-53 & .55 \\
\hline
\end{tabular}




\section{Chapter One: Introduction, Scope and Limitation}

The period during and immediately after World War I, 1914-1920, saw a profound nationalistic fervor against foreign elements in French musical circles. ${ }^{1}$ This new musical enthusiasm was a direct reaction to the late nineteenth-century influences of ultra-chromaticism, especially of Wagner, and picturesque and exotic romanticism, which were then prevalent in Paris. This reaction was also directed against expressionism in early twentieth-century music: the dissonant and atonal features of Schoenberg and Berg. In addition, the piano works of Debussy and Ravel, distinguished by their light, delicate, evocative, and colorful characteristics, also received sharp criticism from the French musical nationalists. ${ }^{2}$ Jean Cocteau and Erik Satie were significant leaders of this movement.

Before the war, Erik Satie had found considerable affection, fame and reputation for his unique music, especially from Parisian avant-garde artists. His compositions mainly consisted of

\footnotetext{
${ }^{1}$ For convenience, "the war" will be used to refer to the First World War in this treatise. 2
}

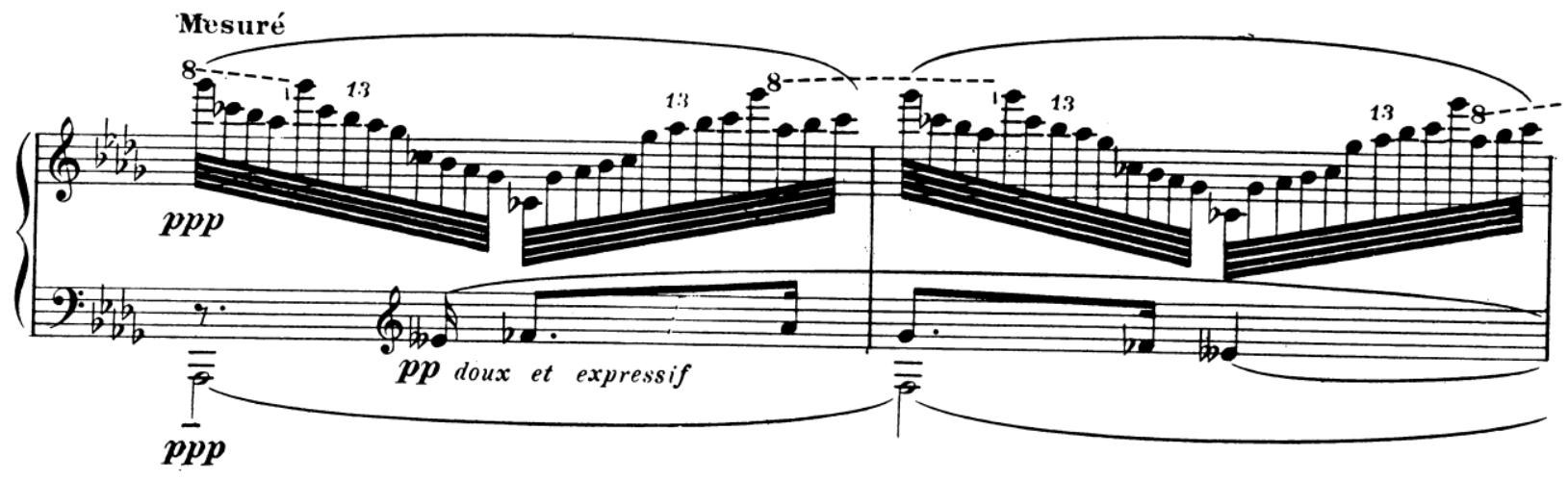

Debussy: Reflets dans l'eau (From Image I) mm. 24-25.

The Cocteau-Satie aesthetics oppose certain pianistic styles of Debussy and Ravel illustrated by the above excerpt. This virtuosic passage displays the melody in the upper line of left hand accompanied by sweeping arpeggios in the right hand. 
short and simple piano pieces with ironic and sarcastic titles. Satie strongly advocated for a distinctive French style, different from Germanic emotionalism, saying:

I explained to Debussy the necessity for a Frenchman to free himself from the Wagnerian adventure which in no way corresponded to our national aspirations. And I told him I was not anti-Wagner in any way but that we ought to have our own music. ${ }^{3}$

One of the early supporters and advocates of Satie's diverging style was Jean Cocteau, a French novelist, dramatist and writer. Cocteau also emphasized establishing distinctly modern French arts, and expressed his views along the lines of Satie:

When I speak of the "Russian trap" or "Russian influence," I do not mean by that that I despise Russian music. Russian music is admirable because it is Russian music. RussianFrench music or German-French music is necessarily bastard, even if it be inspired by a Mussorgsky, a Stravinsky, a Wagner, or a Schoenberg. The music I want must be French, of France. ${ }^{4}$

Cocteau believed in "a desire to return to firm outlines in art, a desire to strip it of the superfluous ornament with which they said it had become bedecked." ${ }^{5}$ In Satie's short piano pieces, Cocteau found a perfect recipe for his perceived artistic nationalism. The 1917 premier of Parade, a ballet with libretto, music and design by Cocteau, Satie and Pablo Picasso respectively, "more than any single event at that time, set the tone for the postwar years."6 Parade was an instant success, with its general style reflecting clarity, simplicity, and objectivity. The ballet was notably received with reverence from a group of young Parisian composers who would later become Les Six and would incorporate its stylistic traits in their works.

\footnotetext{
${ }^{3}$ Myers, Rollo H. Erik Satie. New York: Dover Publications, 1968, 32-33.

${ }^{4}$ Cocteau, Jean, Rollo H Myers, and Pablo Picasso. Cock and Harlequin: Notes Concerning Music. London: Egoist Press, 1921, 19.

${ }^{5}$ Rašín, Vera. "'Les Six' and Jean Cocteau." Music \& Letters 38, no. 2 (1957): 164-65.

${ }^{6}$ Shattuck, Roger. The Banquet Years: The Arts in France 1885-1918. London: Faber and Faber, $1969,154$.
} 
Following the Parade, Cocteau published his manifesto: Le Coq et l'Arlequin (1918), which became an initial blue-print for Les Six's artistic aims. Some of the important elements discussed in the manifesto were simplicity, terseness, and clarity. Others included the exclusion of nineteenth-century decorative elements and vagueness (in visual art, this would include impressionism) and the inclusion of circus motifs, dance hall tunes, and American jazz. The manifesto also put emphasis on percussive rather than lyrical style, and mechanical sounds. ${ }^{7}$ Such passages include:

We may soon hope for an orchestra where there will be no caressing strings. Only a rich choir of wood, brass and percussion. ${ }^{8}$

and:

It would be a fine thing for a musician to compose for a mechanical organ, a veritable sound-machine. We should then hear properly employed, the rich resources of this apparatus which are now lavished, haphazard, upon hackneyed tunes. ${ }^{9}$

In instrumental works, the focus shifted from forms inspired by extramusical ideas, such as nature and literature, to the Baroque and eighteenth-century objective forms. This shift shows the Neoclassical tendencies of the post war. The Oxford Music Dictionary precisely explains the Neoclassicism that Cocteau advocated as:

A movement of style in the works of certain $20^{\text {th }}$-century composers, who particularly during the period between the two world wars, revived the balanced forms and clearly perceptible thematic process of earlier styles to replace what were, to them, the increasingly exaggerated gestures and formlessness of late Romanticism. ${ }^{10}$

\footnotetext{
${ }^{7}$ Parade had already used sirens, typewriters, airplanes and similar mechanical sounds before Cocteau wrote Le Coq et l'Arlequin.

${ }^{8}$ Cocteau et al., Cock and Harlequin, 24.

${ }^{9}$ Ibid, 24.

${ }^{10}$ Whittall, Arnold. 2001 "Neo-classicism." Grove Music Online. 12 Mar. 2019. http://www.oxfordmusiconline.com/grovemusic/view/10.1093/gmo/9781561592630.001.0001/omo9781561592630-e-0000019723.
} 
Articles by journalist Henri Collet published in Comæedia formally established Les Six, certain young Parisian musicians, as a group in 1920. The members of Les Six included Georges Auric (1899-1983), Louis Durey (1888-1979), Arthur Honegger (1892-1955), Darius Milhaud (1892-1974), Francis Poulenc (1899-1963) and Germaine Tailleferre (1892-1983). Les Six was a group of close friends, rather than a group with unified and identical musical aspirations.

Nevertheless, for a brief period their post-war works diligently followed the musical aesthetics of Cocteau and Satie. Norman Demuth describes the group's early musical direction:

"Les Six," being extremely voluble, proclaimed their individual views in no uncertain manner and they practiced everything they preached. Their ideas sounded novel and, helped by snobbery, they were able to propound their views as dogmas. ${ }^{11}$

These young composers, devoted admirers of Satie's music, started performing together as early as 1917. Satie, in turn, appreciated and promoted them as Les Nouveaux Jeunes (the New Young Ones), and became their musical guardian. During the peak of their association in 1920, the group published Album des Six, a six-piece piano set. All six composers contributed one piece each and the set incorporated the Cocteau-Satie French musical elements meticulously. This Album was the only published work of all six composers to reflect this pivotal era of French culture and arts of the early twentieth century. Soon afterwards, Les Six went their separate musical ways.

The works in Album des Six were not composed in order to be part of a collaborative work. Rather, it is a collection, assembled for publication, to symbolize Les Six as a coherent group. They were primarily designed as independent pieces rather than movements of a suite. The pieces of the set were mostly composed in 1919 except for Milhaud's Mazurka and

\footnotetext{
${ }^{11}$ Demuth, Norman. French Piano Music: A Survey with Notes on Its Performance. London: Museum Press, 1959,
} 115. 
Honegger's Sarabande, written in 1914 and 1920, respectively. Interestingly, Milhaud's piece even predates the Satie-Cocteau association that began in 1915, and the joint appearances of Les Nouveaux Jeunes. This suggests or possibly indicates that the composers were not anticipating a joint collaboration while writing these pieces. Nevertheless, they were aware of the stylistic features in these pieces that aligned with the perceived Les Six directions and aspirations. Album des Six is organized alphabetically by composers' last names and contains following pieces:

$\begin{array}{ll}\text { Prélude (1919) } & \text { Auric } \\ \text { "Romance sans Paroles" (1919) } & \text { Durey } \\ \text { Sarabande (1920) } & \text { Honegger } \\ \text { Mazurka (1914) } & \text { Milhaud } \\ \text { "Valse in C" (1919) } & \text { Poulenc } \\ \text { Pastorale (1919) } & \text { Tailleferre }\end{array}$

Martin Cooper describes Les Six's general compositional styles:

Works were kept as a general rule small, avoiding at all costs pretentiousness and anything that could possibly engender boredom. Melodies were extravagantly simple, imitating or even reproducing the contours and emotional quality of nursery tunes or music-hall songs. Rhythms were either correspondingly simple $-2 / 4$ or $4 / 4$ or else very complex, with odd interrupting bars of quintuple or septuple time... primitive syncopations of the fashionable "jazz" were at first used as occasional decoration rather than part of a general rhythmic scheme. ${ }^{12}$

Album des Six contains a diverse blend of pieces, but they are all indeed short and devoid of ornaments and flourishes. Even while displaying stylistic diversity, the pieces in the set all exhibit Cooper's generalized musical descriptions, from Poulenc's simple, static and repetitive Valse to Tailleferre's rhythmic complexities demonstrated in Pastorale. This consistent element,

\footnotetext{
${ }^{12}$ Cooper, Martin. French Music: From the Death of Berlioz to the Death of Fauré. London: Oxford University Press, 1951, 185.
} 
this organizing principle in the Album des Six, is Neoclassicism. While the term was defined in a general sense above, the set specifically correlates the concept with the concept of "return" to earlier principles as elaborated upon by Elliott Antokoletz regarding modern music:

Some twentieth-century composers of the Neoclassical tradition have drawn not only from late eighteenth-century Classical forms and tonality, but also from the polyphonic forms and modalities of the Renaissance composers. However, if you rely on the concept of "return" to earlier principles of objectivity and control as well as established formal principles (sonata, suite, symphony, etc.) and procedures (canon, fugue, etc.) for subsuming a body of music under the Neoclassical heading, then most contemporary music would qualify. ${ }^{13}$

For the Album, Arnold Whittall succinctly captures its general principles of tonal design: ....a neo-classicist is more likely to employ some kind of extended tonality, modality or even atonality than to reproduce the hierarchically structured tonal system of true (Viennese) classicism. ${ }^{14}$

As an opener, Auric's Prélude anticipates the two recurring elements of tonal ambiguity and bitonality that recur throughout the set. ${ }^{15}$ The movements Sarabande, Valse and Mazurka, borrow forms from both eighteenth and nineteenth centuries. Extramusical suggestions in Durey's "Romance sans Paroles" and Tailleferre's Pastorale indicate the Romantic leanings. Hence, Neoclassicism is used broadly, without drawing elements from a specific period in history.

This study is primarily concerned with Album des Six. It will therefore exclude further discussion of any other music. Album des Six not only demonstrates the youthful styles of the composers, but also offers an engaging and effective pedagogical work for early-advanced piano

\footnotetext{
${ }^{13}$ Antokoletz, Elliott. Twentieth-Century Music. Englewood Cliffs, N.J.: Prentice Hall, 1992, 243.

${ }^{14}$ Whittall, Arnold. 2001 "Neo-classicism." Grove Music Online. 12 Mar. 2019.

http://www.oxfordmusiconline.com/grovemusic/view/10.1093/gmo/9781561592630.001.0001/omo-

9781561592630-e-0000019723.

${ }^{15}$ The pieces show tonality, tonal ambiguity and a tonal center. However, the set does not include atonality.
} 
students. ${ }^{16}$ While furthering a Satie-Cocteau vision of nationalism, they also reflect their composers' appreciation of the achievements of other then-prominent Parisian composers including Debussy, Stravinsky and Florent Schmitt. This variety of influences demonstrates the richness of this concise collection. The pieces of the set are short, pianistic, direct, yet rarely performed; they make attractive repertoire for both the teaching studio and the concert hall. This document should aid in their dissemination, appreciation, and understanding.

${ }^{16}$ Members of Les Six were in their 20s and were not fully established composers when Album des Six was published. 


\section{Chapter Two: Background and Related Literature}

While covering the French avant-garde of the early twentieth century, the chronicles of music history discuss Les Six consistently, yet briefly. Often, a point that is central to this discussion is the formation of the group, a formation which grew from concerns regarding foreign influences in French music. This context is explored in many sources. Several are particularly pertinent. French Music: From the Death of Berlioz to the Death of Faure by Martin Cooper provides a great synthesis regarding Satie, Cocteau, Les Six, and changing Parisian musical aesthetics. ${ }^{17}$ Similarly, the chapter: "The Rise of Neoclassicism in France: The CocteauSatie era and 'Les Six"” by Elliott Antokoletz sufficiently summarizes the musical elements and forms of Les Six. ${ }^{18}$ In addition, the following books are particularly valuable resources to understand the Parisian artistic circle and the formation of Les Six; though they will not be cited directly, they were essential background reading for this research paper: ${ }^{19}$

- The Banquet Years: The Origins of the Avant-Garde in France - 1885 to World War I, by Roger Shattuck

- Paris The Musical Kaleidoscope, 1870-1925, by Elaine Brody

Of the six composers, Poulenc left the most lasting musical legacy, followed in importance by Milhaud and Honegger. In general histories of music, Auric, Durey and Tailleferre are known only as members of the same group. In volumes of piano literature by authors such as Norman Demuth, F. E. Kirby, and James Gibb, Les Six also frequently receives passing mention while discussing Poulenc. Once again, Poulenc's piano output has enjoyed

\footnotetext{
${ }^{17}$ Cooper, Martin. French Music: From the Death of Berlioz to the Death of Fauré. London: Oxford University Press, 1951.

${ }^{18}$ Antokoletz, Elliott. Twentieth-Century Music. Englewood Cliffs, N.J.: Prentice Hall, 1992.

${ }^{19}$ This treatise will not cite these books despite their immense value to describe Parisian atmosphere and Les Six.
} 
prominence in the literature in comparison with other members of the group. These books also consistently mention Album des Six briefly as a unique collection that resulted from an equally unique artistic movement. The set contains an eclectic collection of pieces that reflect both the personalities of the composers and their shared aesthetics, which were new at the time.

The purpose of this treatise is to address Album des Six, the only published work of Les Six, as a pedagogical work for piano, especially the distinctly French musical elements and their correlation with the ideas proposed by Jean Cocteau in his Le Coq et l'Arlequin. The details of the formation of the group are not essential for this study, and many existing literatures adequately cover this aspect. Nevertheless, in order to establish the groundwork for the discussion of the set it is helpful to synthesize briefly the following components: Erik Satie and his few piano works; the Salle Huyghens concerts; the Cocteau-Satie association and their collaborative work, Parade; and Cocteau's manifesto.

Erik Satie was an influential musician in Paris when the war broke out. ${ }^{20}$ He spent his youthful years as a cocktail pianist in Montmartre district of Paris after brief attendance at the Paris Conservatoire. At the age of forty, Satie resumed his musical studies at the Schola Cantorum, emphasizing counterpoint with Vincent d'Indy and Albert Roussel. During the war, the Parisian avant-garde circle firmly embraced Satie and his music, and featured his works prominently in their gatherings. Books on piano literature regularly discuss Satie's piano works, which are mostly short character pieces, for their uniqueness: especially their evocative, humorous and improvisatory nature. Satie's early works such as Trois Gymnopédies (1888) reflect the influence of café and popular music and exhibit his characteristic style: lyrical

20 "The war" refers to World War I in this treatise, as mentioned in the previous chapter. 
melodic line, chordal accompaniment, and clear and balanced phrase structure. His piano pieces were radical in comparison with the existing pianistic style due to their intentional avoidance of virtuosity. Nevertheless, Satie's deliberate simplicity received praises from Parisian artists such as Cocteau, Ravel, Debussy and Les Six. ${ }^{21}$
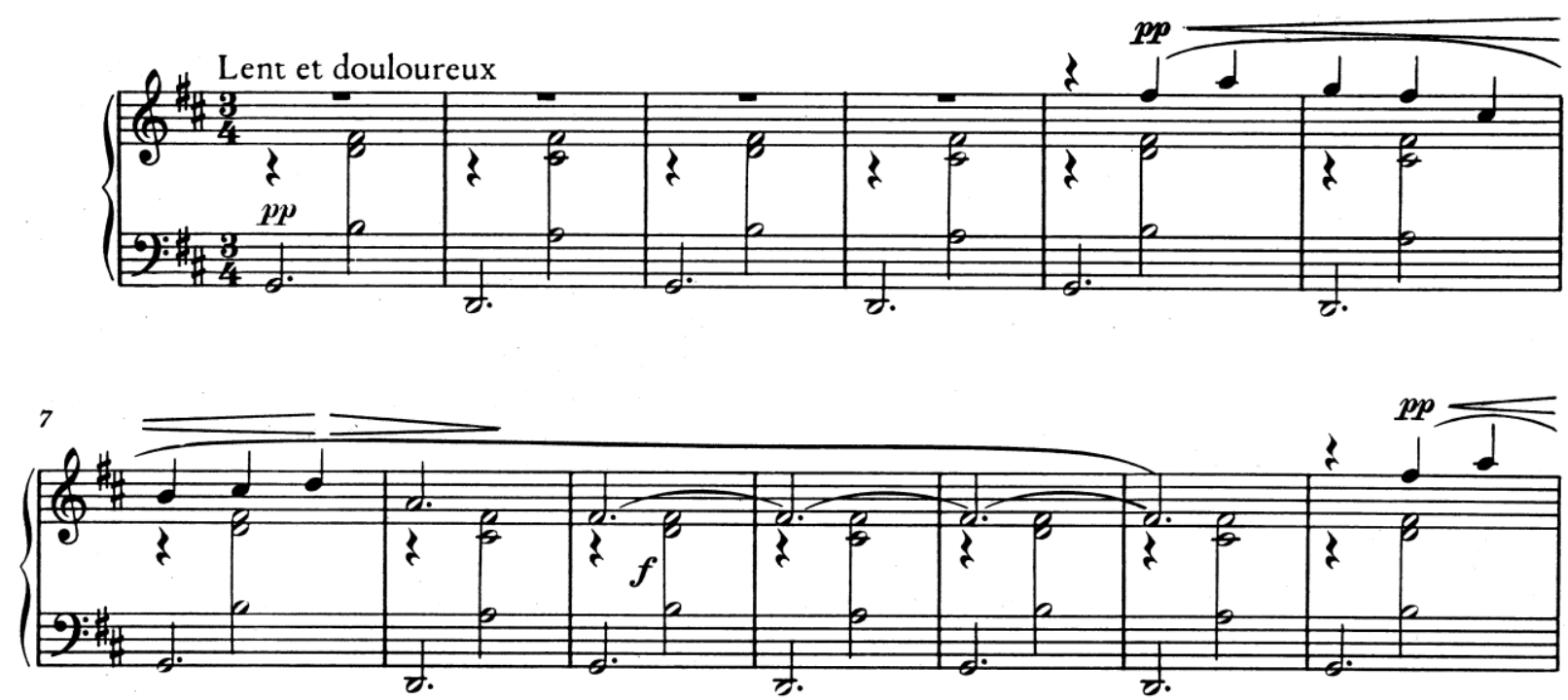

Figure 1. Erik Satie: Gymnopédie \#1, opening.

F. E. Kirby describes Satie's anti-Romantic approach thus:

What is most striking in comparison with German Romantic music is the directionless quality; the pieces seem static, they lack a climax and central point, and they do not go anywhere - they simply are. ${ }^{22}$

Satie's later works such as Embryons desséchés (1913) show innovation and his fondness for humor and satire, in addition to his earlier traits.

\footnotetext{
${ }^{21}$ In admiration of Satie's works, Debussy orchestrated two of Satie's Trois Gymnopedies.

22 Kirby, F. E. A Short History of Keyboard Music. New York: Free Press, 1966, 391.
} 
Crustacés à yeux sessiles, c' est-à-dire sans tige et immobiles. Très tristes de leur naturel, ces crustacés vi vent, retirés du monde, dans des trous percés à travers les falaises.
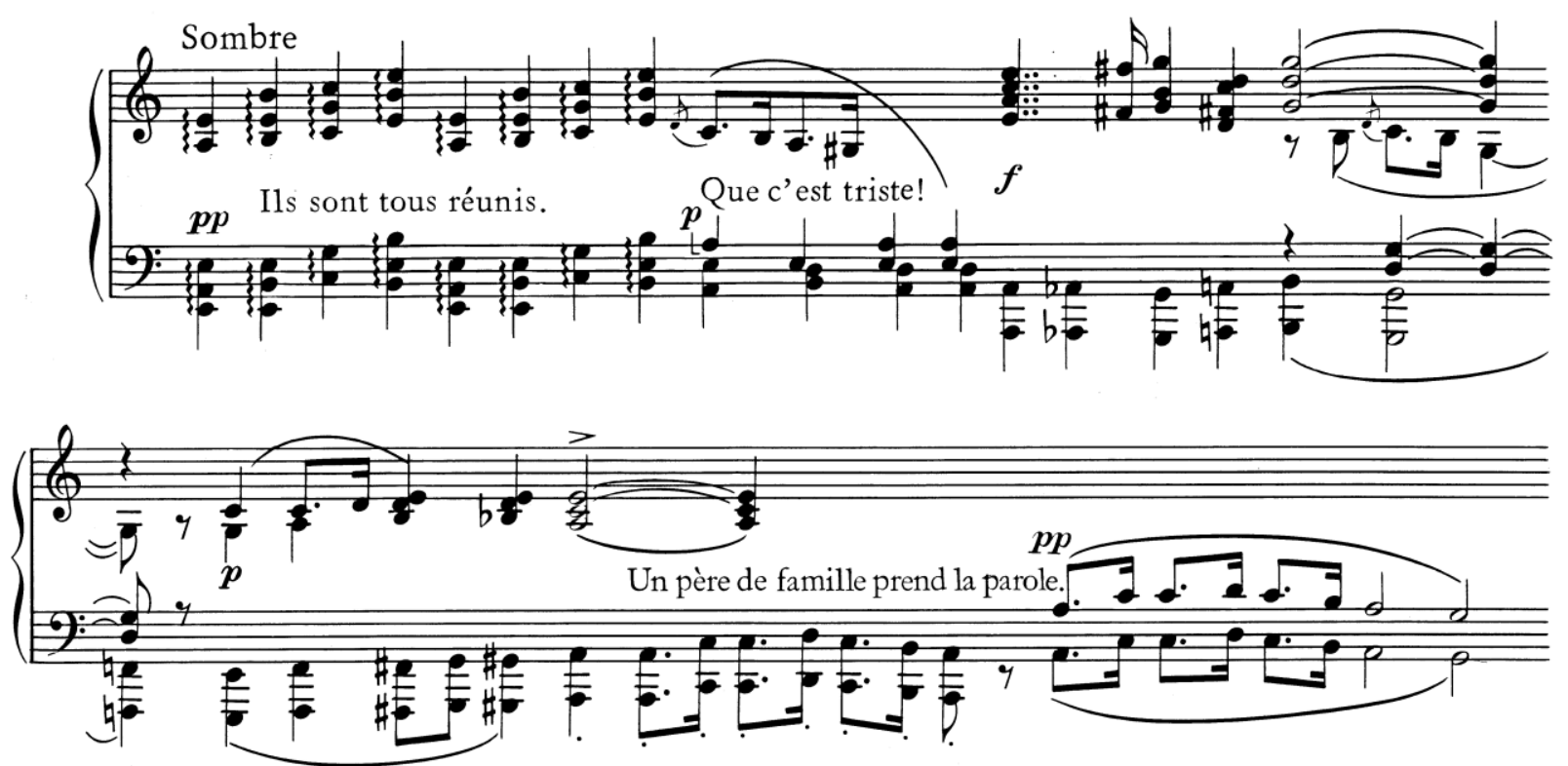

(Citation de la célèbre Mazurka de Schubert)

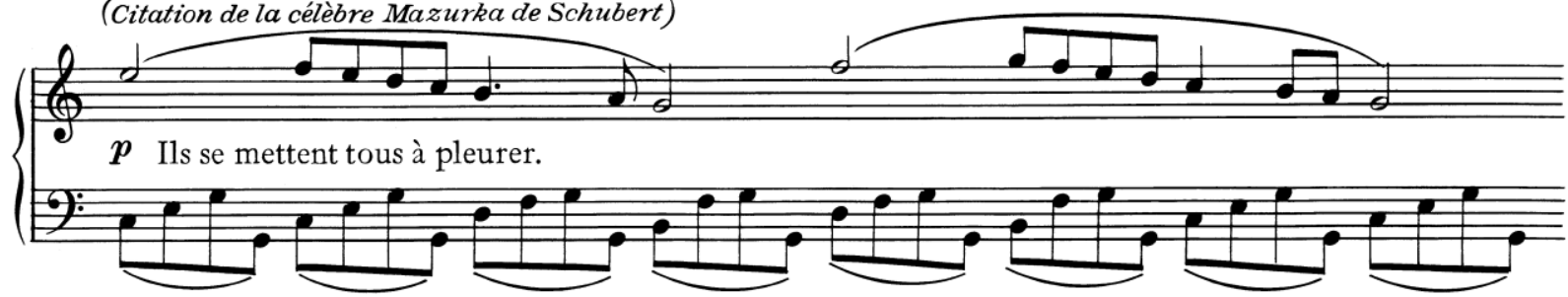

Figure 2. Erik Satie: “d'Edriophthalma," the opening section from Embryons desseches.

This piece (Figure 2) provides neither a time signature nor bar lines. Nevertheless, the phrasing and contours clearly indicate a common [duple] meter. As an illustration of the humor at the textual remarks, Satie indicates a Mazurka by Schubert (Schubert composed no Mazurkas) while quoting Chopin's third movement (Marche Funebre: Lento) of the Piano Sonata no. 2, Op. 35. Satie's titles and commentaries, which reflects his iconoclastic and eccentric personality, receive considerable discussions regarding whether they contribute to the music, especially to a listener. Cooper describes Satie's titles and commentaries accordingly: 
The running commentary printed above the musical text continued the nonsense tradition, sometimes amusingly but often with an obvious desire to astound.... [This]can only be considered amusing by those for whom Satie's wit is an article of faith. ${ }^{23}$

Similarly, Poulenc says this about Satie's piano works and their titles:

Satie's piano music isn't appreciated at its real value, probably because of his titles...obviously off-putting to see, printed in programmes: Apercus desagreables (Unpleasant glimpses), Danse de traverse (Crooked dance).... Yet, what wonderful music!!..... You must forget the farcical literature that surrounds these tiny pieces, let yourself go, and their charm will work. ${ }^{24}$

The War seemed unintentionally to offer an opportunity for new artistic ideas to flourish in Paris. ${ }^{25}$ Due to restrictions and limitations on public gatherings in large social places such as theatres, alternate private platforms were created. Some of these venues included Salle Huyghens and Theatre $d u$ Vieux-Colombier, and were used for entertainment and artistic expressions. ${ }^{26}$ Salle Huyghens provided weekly ticketed concerts for its members and their guests in order to raise funds for unemployed musicians and artists. Satie enjoyed considerable prominence and fame in these progressive concerts. His music was respected and celebrated by composers including Debussy, Ravel, and Stravinsky. Myers quotes Templier's description of Satie's innovative music and its influence on the avant-garde artists:

Erik Satie occupies a very special place in the history of contemporary art. Isolated and aloof from the times in which he lives he has already written some short pieces which prove him to be a 'forerunner' of genius. These works, unhappily too few in number, are surprising for the way in which they anticipated the modernist vocabulary, and for the almost prophetic character of certain harmonic inventions which they contain....M. Claude Debussy paid a striking tribute to this subtle 'explorer' by orchestrating two of his

\footnotetext{
${ }^{23}$ Cooper, French Music, 181.

${ }^{24}$ Poulenc, Francis. My Friends and Myself: Conversations [with] Francis Poulenc. Compiled by Stéphane Audel. Translated by James Harding. London: D. Dobson, 1978, 70-1. Translations of the titles are included in the original. ${ }^{25}$ Frederick Brown provides a comprehensive summary of artistic activities in private studios of Paris during the war in the chapter "Arts and Craft" of An Impersonation of Angels: A Biography of Jean Cocteau. New York: Viking 1968, 155-61.

${ }^{26}$ Salle Huyghens was an art studio and belonged to a prominent artist, Emile Lejeune. The studio, transformed into a small concert hall, provided weekly performances on Saturday evenings.
} 
Gymnopédies which were performed at a concert of the Société Nationale; while M. Maurice Ravel, by playing today the second Sarabande, which bears the astounding date of 1887, bears witness to the esteem which is felt by the most 'advanced' composers for the creator who a quarter of a century ago was already speaking the daring musical 'jargon' of tomorrow. ${ }^{27}$

In 1915, Satie's distinctive style attracted a young Parisian artist, Jean Cocteau. He was a writer, poet, critic; later, he was also a brilliant spokesman for Les Six. Cocteau advocated for new artistic aims, free of foreign influences, and he found inspiration in Satie's music. At the Salle Huyghens, Cocteau was so impressed after hearing Trois morceaux en forme de poire (Three Pieces in the Shape of a Pear), a piano duet written by Satie and performed by Satie and Ricardo Viñes, that he proposed a collaboration with Satie. His proposal was for the ballet, Parade.

The affiliation between Satie and Cocteau is a pivotal moment in Parisian arts during the war. Both enjoyed considerable fame in avant-garde circles. Their successful collaboration on the ballet Parade in 1917 had a significant impact. Parade's music, stylistically an extension of Satie's small humorous piano pieces, primarily emphasized simplicity, melody and colors. It also featured mechanical sounds such as typewriters, sirens and whistles. Its musical features of simplicity, clarity, terseness, neoclassicism, tonal ambiguity, and jazz elements later became a basis for Cocteau's manifesto: Le Coq et l'Arlequin, and the initial musical aesthetics of Les Six. ${ }^{28}$ Regarding the influence of Parade, Frederick Brown states:

Parade was only the first step. Between its performance and its revival three and a half years later, Cocteau appropriated not merely a ballet but a whole musical movement. By

\footnotetext{
27 Myers, Rollo H. Erik Satie. New York: Dover Publications, 1968, 42.

${ }^{28}$ Brown (Impersonation of Angels, 149-50) describes some important musical excerpts of Parade as being the fugue for string quartet, "the First Manager" dance music: which is "neither major nor minor, neither tonal or atonal", "monotonous and compulsive," and "the Little American Girl dance which incorporates jazz titled - The Steamship Rag."
} 
1919 he had become the spokesman and ex post facto organizer of a group of young composers eventually dubbed the Six. ${ }^{29}$

Satie incorporated café and music hall styles, which attracted both admirers and adversaries such as Poulenc and Poueigh respectively. ${ }^{30}$ Poulenc gives his impression of Parade hence:

I was conquered! With all the injustice of youth, and although I idolized Debussy, I agreed to disown him a little because I was so eager for the new inspiration Satie and Picasso [who designed the costumes and sets] were bringing us....Satie's music, so simple, so bare, so ingenuously clever, like a picture by the Douanier Rousseau, caused a scandal with its flippancy. For the first time - it's made up for it since - the music hall invaded art with a capital A....Up in the "Gods" the whole of Montparnasse was yelling....Auric, Roland-Manuel, Tailleferre, Durey and many other musicians bawled: "Vive Satie!" 11

Poulenc's contemporary colleagues, including later members of Les Six, some already included in his quote, shared similar admiration for Satie and his music. ${ }^{32}$ The young composers started performing together in Salle Huyghens, Vieux Colombier and similar venues as early as 1917. Satie promoted them as Les Nouveaux Jeunes and became their musical guardian. ${ }^{33}$ Cocteau also supported and promoted them as a cohesive group. This led to articles by journalist Henri Collet published in Comoedia in 1920 that formally established the group. Poulenc reacted to Collet's articles and the formation of Les Six as being "a critic needing a slogan to baptize the French Les Six, on the model of the famous "Five" Russian composers." 34 Similarly, Milhaud describes the formation of group and their cohesiveness accordingly:

\footnotetext{
${ }^{29}$ Brown, Impersonation of Angels, 155.

30 Jean Poueigh, a music critic, wrote a nasty review about Parade's music. In turn, Satie sent him a post card with an obscene remark, for which he was sued and eventually sentenced to eight days in prison: Ibid, 153.

31 Poulenc, My Friends and Myself, 68.

${ }^{32}$ Alexis Roland-Manuel was a composer who became a critic and, later, a professor of aesthetics at the Paris Conservatoire.

${ }^{33}$ Les Nouveaux Jeunes, forerunners of Les Six, initially consisted of Auric, Durey, Honegger, and Tailleferre.

34 Ibid, 42.
} 
The critic Henri Collet published in Comoedia a chronicle entitled "Five Russians and Six Frenchmen." Quite arbitrarily he had chosen six names: Auric, Durey, Honegger, Poulenc, Tailleferre, and my own, merely because we knew one another, were good friends, and had figured on the same programs; quite irrespective of our different temperaments and wholly dissimilar characters. Auric and Poulenc were partisans of Cocteau's ideas, Honegger derived from the German romantics, and I from Mediterranean lyricism. I fundamentally disapproved of joint declarations of aesthetic doctrines and felt them to be drag, and unreasonable limitation on the imagination of the artist....Collet's article excited such world-wide interest that the "Group of Six" was launched, and willy-nilly I formed part of it. ${ }^{35}$

Cocteau's manifesto, Le coq et l'Arlequin, dedicated to Auric, is an important document for new artistic aesthetics of the post-war period. It proposed distinctive elements devoid of foreign influence. The elements included simplicity, economy, and gesture. Such economy put greater emphasis on melody, and other elements played supportive roles to enhance the melody. It also advocated using only essential musical elements and confronted the excessive flourishes of pianistic gestures, the latter aimed at certain characteristic piano works of Debussy and Ravel:

Sick to death of flabbiness, fluidity, superfluity, frills, and all the modern sleight-of-hand, though often tempted by a technique of which he knows the ultimate resources, Satie voluntarily abstained, in order to "model in the block" and remain simple, clear and luminous. ${ }^{36}$

Cocteau's manifesto had mixed receptions, positive from critics and dismissive from some members of Les Six. Nevertheless, their Album des Six shows Cocteau's proposed elements. Milhaud describes the document accordingly:

In the course of the winter, Cocteau published a book that created a great stir: Le Coq et l'Arlequin. In this little treatise on aesthetics, he attacked the so-called serious music... and impressionism in the manner of Debussy. He exalted the barbarian feeling of

\footnotetext{
35 Milhaud, Darius. Notes Without Music: An Autobiography. Translated by Donald Evans, (Translator), and Arthur Ogden. Edited by Rollo H Myers and Herbert Weinstock. Da Capo Press Music Reprint Series. New York: Da Capo Press, 1970, 97.

${ }^{36}$ Cocteau, Jean, Rollo H Myers, and Pablo Picasso. Cock and Harlequin: Notes Concerning Music. London: Egoist Press, 1921, 26.
} 
Stravinsky's Le Sacre du printemps, the purity of [Satie's] Socrate, and the astringent art of Auric; he called for a decisively French type of music. Always given to generalization the critics lost no time in hailing Cocteau as the prophet, theoretician, and animator of postwar music. ${ }^{37}$

The citation of Auric demonstrates that Cocteau had Les Six in mind. However, it should be acknowledged that Poulenc later dismissed the manifesto as not referring to nor even serving as an aesthetic foundation for Les Six:

He wasn't our theorist, but our friend and our brilliant spokesman. To tell the truth, his little musical summary, Le Coq et l'Arlequin, is a disguised defense of Satie's aesthetic against Stravinsky's. It is impossible to regard it as a manifesto of Les Six because Arthur Honegger's violent and romantic art is alone enough to contradict it. ${ }^{38}$

Scholarly interests in Les Six, its members, and their works are reflected in various dissertations. For this treatise, "The Album des Six and Pianism in the works of Les Six, 19171925,"39 a DMA dissertation by Michael Sitton, particularly provides complementary materials. Sitton uses 1917 to mark the initial joint appearances of Les Six in concerts as Les Nouveaux Jeunes. He marks Satie's death in 1925 as the concluding year of Les Six, thereby making Satie an important symbolic figure. His dissertation broadly focuses on three important aspects of Les Six: the Parisian cultural environment, its influence on their formation, and a survey of their piano works written between 1917 and 1925. Although Album constitutes a central component of his survey, the set receives relatively limited space and scope. The chapter on the set is short and includes basic analysis, adequate for his treatise. The major strength of his work is the chapters

\footnotetext{
${ }^{37}$ Milhaud, Notes Without Music, 97.

38 Poulenc, My Friends and Myself, 43.

${ }^{39}$ Sitton, Michael Randy. "The "Album Des Six" and Pianism in the Works of Les Six, 1917--1925." Order No. 9124490 University of Illinois at Urbana-Champaign, 1991. Ann Arbor: ProQuest. Web. 1 Mar. 2019.
} 
describing the first two aspects. This treatise values Sitton's scholarly work and expands the discussion of Album from a pedagogical point of view.

Similarly, Barbara Scheidker's DMA dissertation: Cultural Influences on the Piano Music of Les Six, offers important post-war Parisian cultural and aesthetic values. ${ }^{40}$ Her investigation of three important artistic movements: Cubism, Futurism, and Dada, in specific works of Les Six is particularly valuable. Her treatise concludes with Poulenc's Mouvement Perpetuels (1918) as a synthesis of all three. In addition, Janelle Gelfand's dissertation discusses the instrumental works of Tailleferre. This includes genres such as solo piano, duet and chamber music. ${ }^{41}$ Likewise, Jon Nelson focuses on piano works of Poulenc in his dissertation. ${ }^{42}$ All these treatises briefly mention the pieces of the Album, but do not provide significant resources specific to this study. Hence, this treatise will neither cite nor directly use these dissertations.

\footnotetext{
${ }^{40}$ Scheidker, Barbara Eileen. "Cultural Influences on the Piano Music of "Les Six"." Order No. 9617399, The University of Texas at Austin, 1995.

${ }^{41}$ Gelfand, Janelle Magnuson. "Germaine Tailleferre (1892-1983): Piano and Chamber Works." Order No. 9936029 University of Cincinnati, 1999. Ann Arbor: ProQuest. Web. 1 Mar. 2019.

${ }^{42}$ Nelson, Jon Ray. "The Piano Music of Francis Poulenc." Order No. 7820754 University of Washington, 1978. Ann Arbor: ProQuest. Web. 1 Mar. 2019.
} 


\section{Chapter Three - Pedagogical Thoughts}

Album des Six, a collection of six short pieces, is the only joint publication of Les Six. The set consists of diverse pieces, each often focusing on one idea or mood, while the collection as a whole retains the Cocteau-Satie aesthetics of simplicity, clarity and directness as an underlying foundation. It should be re-emphasized that the works were not composed in order to be a part of a set. Therefore, the pieces are independent and do not offer themselves as a coherent set. However, there are consistent shared common elements such as sectional organization, balanced phrase structure, and tonal ambiguity: that is, they frequently embrace bitonality and extended harmony. The set is organized alphabetically by composers' last names and consists of pieces with varying technical and musical sophistications. The following suggests an ordering in which the pieces might be assigned, based on technical difficulty (easy to difficult):

$\begin{array}{ll}\text { Mazurka (1914) } & \text { Darius Milhaud } \\ \text { Prélude (1919) } & \text { Georges Auric } \\ \text { "Valse in C" (1919) } & \text { Francis Poulenc } \\ \text { Pastorale (1919) } & \text { Germaine Tailleferre } \\ \text { "Romance Sans Paroles" (1919) } & \text { Louis Durey } \\ \text { Sarabande (1920) } & \text { Arthur Honegger }\end{array}$

By coincidence, this also approximates a chronological ordering, although the completion dates of the four works from 1919 has not been explored.

This chapter discusses each piece of the Album and follows the original alphabetical order. The model for each piece in the chapter includes a brief introduction of the composer focusing mainly on their piano works up until 1920. Then follow some general observations, continuing with a walk-through of each piece's sections, first covering musical and technical 
features, then offering suggestions for technical and interpretive purposes, which are based on the author's perspective. The pieces offer room for personal interpretation of the performers. In order to demonstrate and discuss specific aspects of the works as clearly as possible, the chapter will include musical excerpts but not the entire scores. The full scores are freely available online and easily accessible. 


\section{Prélude (1919) - Georges Auric}

Album des Six opens with a simple, yet expressive, Prélude by Georges Auric (18991983), a prolific composer of stage and film music. Auric started composing from the age of 10 and received considerable praise and appreciations from such composers as Florent Schmitt, Charles Koechlin and Albert Roussel. Unfortunately, he later destroyed his early works. He was also a brilliant pianist and frequently performed Erik Satie's piano works, which had a profound influence on him. Auric, along with Poulenc (the two of them are the youngest members of the group), was an ardent supporter of the Satie-Cocteau aesthetics. His most important early piano work is Adieu, New-York! (1919). Other early surviving piano works include Gaspar et Zoé ou L'après-midi dans un parc (1914) and 3 Pastorales (1919-20).

Prélude is dedicated to General Clapier and was composed in 1919. This short work features some important musical elements such as bitonality, pedal point, and dissonant harmony, which recurs consistently throughout the Album. Melodies are simple and tuneful, influenced by music-hall styles. The harmony is also simple on a surface level, but dissonant due to added notes. This can be seen even in the first two measures, with the A-major triad contradicted by the moving alto voice (Figure 1), creating a subtle dissonance. This piece integrates periodic and balanced phrase structure of mostly four-measure units, each of which can also be sub-divided into two-measure units. It also incorporates percussive, brassy and fanfare-like accompaniments and passages. James Harding has following to say about this piece:

[Prélude's] mocking tone was immediately revealed in the dedication to 'General Clapier.' A military fanfare, lavishly sown with 'wrong' notes, provided the theme of a jeu d'esprit which neither Auric nor anyone else has ever taken seriously. ${ }^{43}$

\footnotetext{
${ }^{43}$ Harding, James. The Ox on the Roof: Scenes from the Musical Life in Paris in the Twenties. New York: St. Martin's Press, 1972, 98.
} 
Prélude consists of four sections with a brief coda. Sections are clearly marked with double bar lines including a repeat of mm. 1-16, and by contrasting tonal centers. The texture is thin and mostly consists of melody and accompaniment. The first and third sections are related by their nearly identical melodies; the beginning of this same melody is repeated at half tempo in the fourth section. The form is:

$\begin{array}{lc}\text { Section I } & \mathrm{mm} \cdot \text { 1-16 } \\ \text { Section II } & \mathrm{mm} \cdot \text { 17-36 } \\ \text { Section III } & \mathrm{mm} \cdot \text { 37-46 } \\ \text { Section IV } & \mathrm{mm} \cdot \text { 47-59 } \\ \text { Coda } & \mathrm{mm} \cdot 60-63\end{array}$

Section I is divided into two subsections, mm. 1-8 and mm. 9-16, with periodic phrases. The opening theme (mm. 1-8) provides important thematic and rhythmic ideas for the entire piece. The melody is simple, essentially outlining the triad in the soprano. An expressive legato, with a loose wrist, relaxed forearm, and minimal finger articulation, is desirable for the opening theme and most melodic phrases throughout the piece. The rhythm of the first bar, often associated with military fanfares and highlighted in the score (Figure 1, m. 1), is a unifying motif, which appears throughout. The harmony mostly hovers around the tonic in mm. 1-8, enriched by added notes, as is easily noticeable in the combination of melody and accompaniment. This tonality is further blurred by the alto counter-melodic line, which suggests $\mathrm{F} \#$ minor tonality. The left hand mostly punctuates the harmony with constant eighth notes and the tonic pedal point (mm. 5-6) in this opening section. The articulation of the left hand here should be soft, detached and percussive. The second part of this section (mm. 9-16) basically underlines dominant harmony over a tonic pedal point. 
Auric's pedal markings are limited and without the release instruction. Change pedal, one per bar, to hold the tonic pedal point in mm. 5-6. Similarly, use one pedal per quarter note in mm. 9-10 and 13-14. In m. 11, use left hand to play F double sharp of the alto voice. When shaping the phrases, one must observe that this section includes four-measure phrase units. Generally, make the first beat of the fourth measure the peak. Harmonically, this section incorporates the secondary dominant $(\mathrm{V} / \mathrm{V})$ at $\mathrm{mm}$. 15-16 before the repeat to conclude the section. This secondary dominant leading to section II is an effective harmonic transition, whereas the harmonic effect when repeating back to the beginning is abrupt. Broaden the last beat at $\mathrm{m} .16$ with crescendo both times. Make an extremely small break at the end of $\mathrm{m} .16$ both times, to heighten the surprise and anticipation.

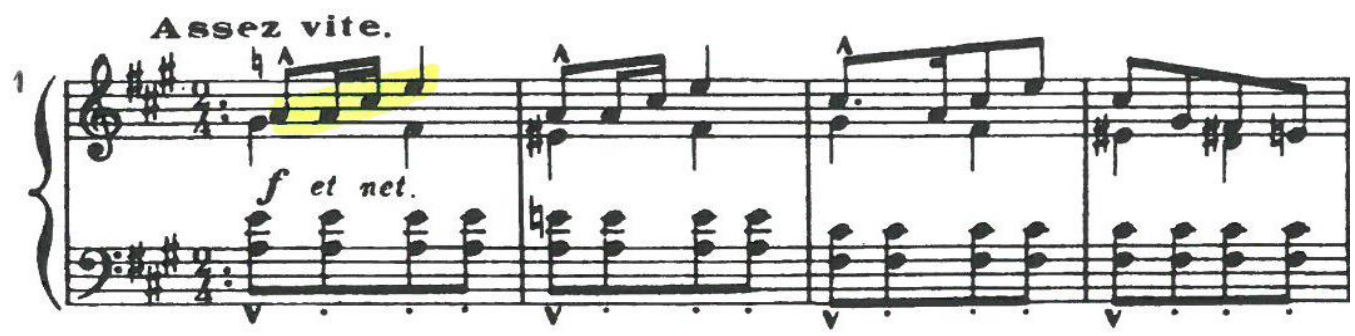

Figure 1. Auric: Prélude, mm. 1-4.

Section II includes the rhythmic motif introduced in $\mathrm{m} .1$ and now restated in various guises: the first such appearance is as a percussive and fanfare-like accompaniment in mm. 17 and 19 (Figure 2). This rhythmic motif, later, even unites melody and accompaniment in mm. 21, 23 and 29. (Figure 2). This section begins and ends in the dominant tonality with a tonal center of $\mathrm{F} \#$ minor inserted in the middle in $\mathrm{mm}$. 23-32. This section also starts with a periodic phrase with a short melodic motif in the soprano and a descending chromatic line in the alto, which serves as motivic idea for the second and third phrases (mm. 21-28). These latter phrases consist of a tuneful duet in the soprano and bass, a development from the chromatic descending line. 
Bring out these expressive lines clearly and smoothly with the dynamic inflections. Use pedal sparingly and cautiously to avoid blurring the smooth melodic line. The last phrase of Section II (mm. 33-36) emphasizes the tonal center of E before implying secondary dominant (V7/ii) in $\mathrm{m}$. 36. Broaden the last beat of this measure slightly to highlight the chromaticism and its relatively rapid harmonic rhythm and to prepare for the next section.
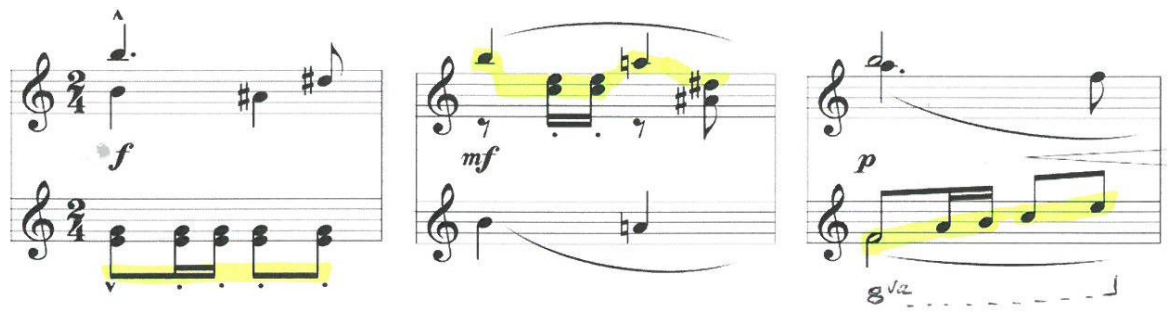

Figure 2. Auric: Prélude, rhythmic motif.

One might expect that m. 36's climactic preparation, with its implied secondarydominant, would lead to the key of F\# minor in $\mathrm{m}$. 37, the beginning of section III. However, Auric has a surprise for the listener. Section III follows with the return of section I and incorporates the bitonal concept of white-key/black-key, with the right hand in the unexpected key of $\mathrm{C}$ major (or A natural minor), while the left hand suggests $\mathrm{Db}$ major (or $\mathrm{Bb}$ minor). Some redistribution of notes will make mm. 37-38 easier and effective for pianists with smaller hands: play $\mathrm{Ab}, \mathrm{Bb}$ and $\mathrm{F}, \mathrm{G}$ with right and left hands respectively (Figure 3: yellow=right, pink=left). From mm. 37-42, lightly press the pedal on the downbeat to add warmth to the harmony. With regard to the hand crossings of mm. 39-46, a hand arrangement of right under left makes it easy to play the passage. In mm. 45-46, the left hand punctuates the intervals of $\mathrm{F} \#-\mathrm{C} \#$ and $\mathrm{G} \#-\mathrm{C} \#$, which should be extremely pointed and secco, to contrast with the smooth descending right hand scale over it. 


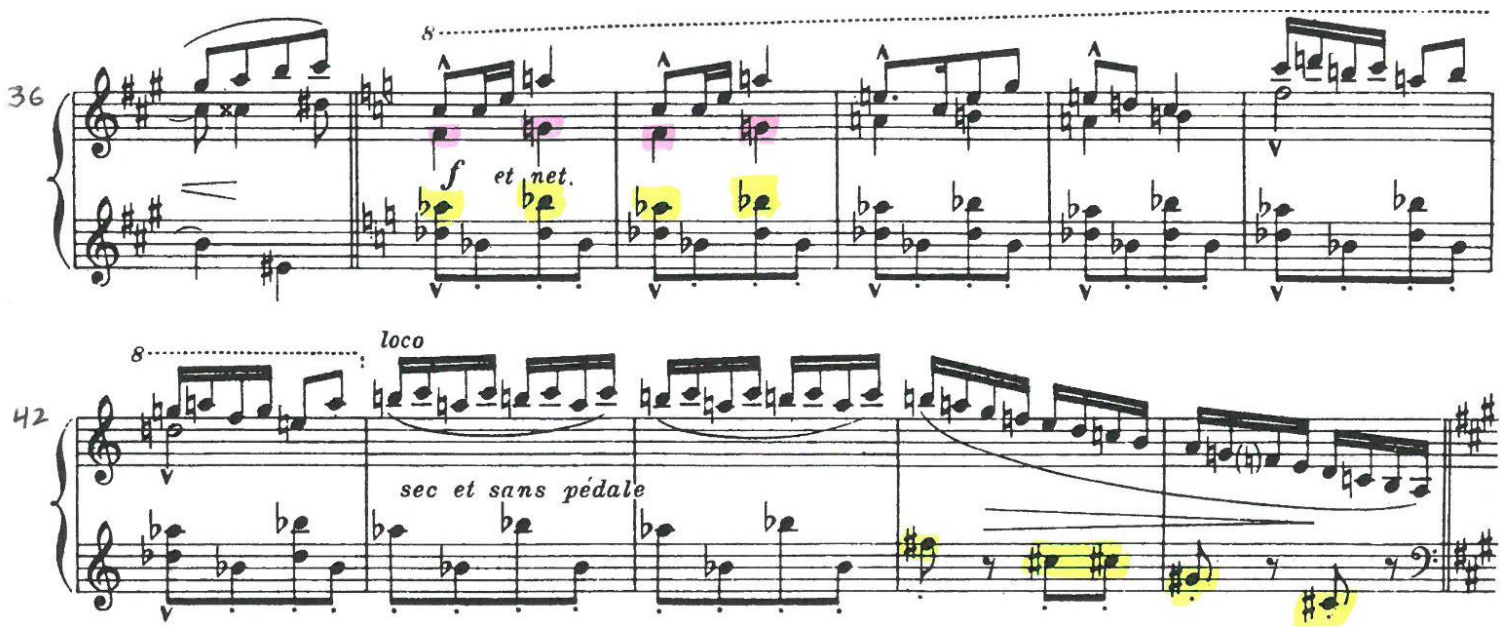

Figure 3. Auric: Prélude, mm. 36-46.

The bass descending intervals of $\mathrm{mm}$. 45-46 provide an important harmonic foundation for the last section. It includes $\mathrm{G} \#$ tonal centers with ambiguous harmonies produced by the intervals of $\mathrm{C} \#-\mathrm{F} \#$ and $\mathrm{C} \#-\mathrm{G} \#$ over a $\mathrm{G} \#$ pedal point. These chordal units consist of threemeasure rather than the prevailing four-measure units of the piece. The right hand integrates soprano and alto lines, the former outlining the triad and the latter descending by step, in $\mathrm{C}$ major, combining the motivic ideas of sections I and II. This section also shows black-key/whitekey bitonality. The phrase unit is $2+2+4$ (Figure 4 , mm. 49-56). A shallow pedaling, changing every quarter note, is appropriate here to keep the melodic lines clear. This section concludes with a caesurae and includes the only irregular unit of three-measures (mm. 57-59). 

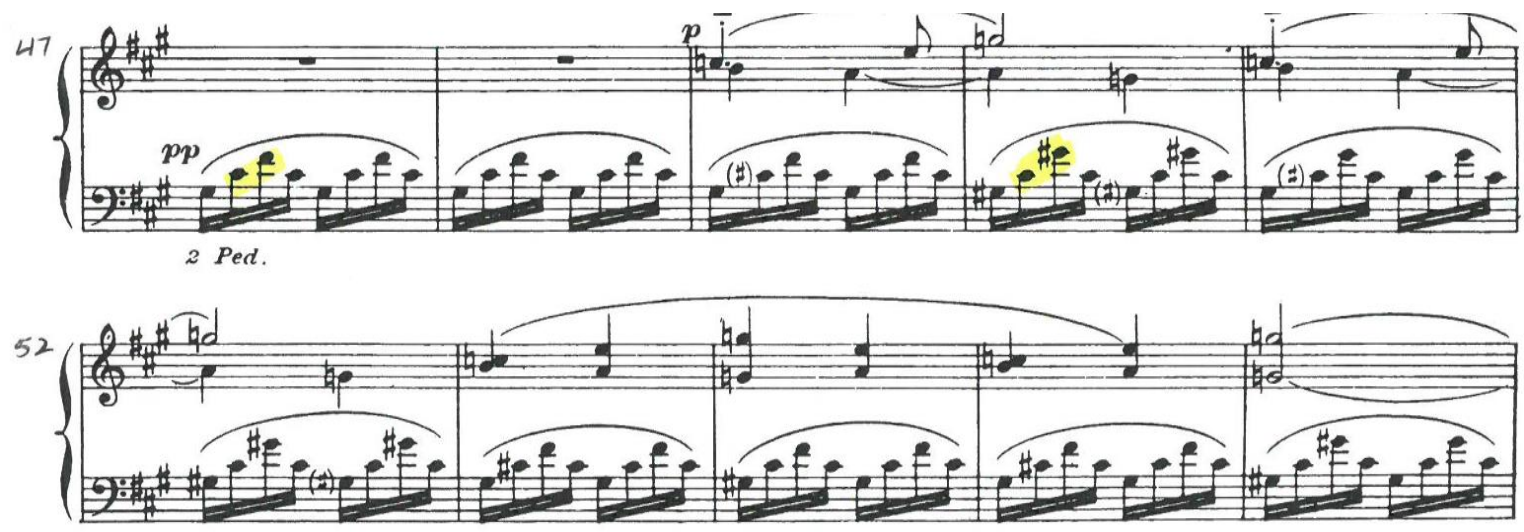

Figure 4. Auric: Prélude, mm. 47-56.

Prélude ends with a short coda comprising a single brassy and fanfare-like phrase. Its strong ending is marked with $\mathrm{V}$-I cadence in mm. 62-63 (Figure 5). Interestingly, the tonic triad first appears in incomplete form; the missing third appears alone afterwards in both hands in the extreme registers of the keyboard to provide a witty conclusion to the piece (m. 63).

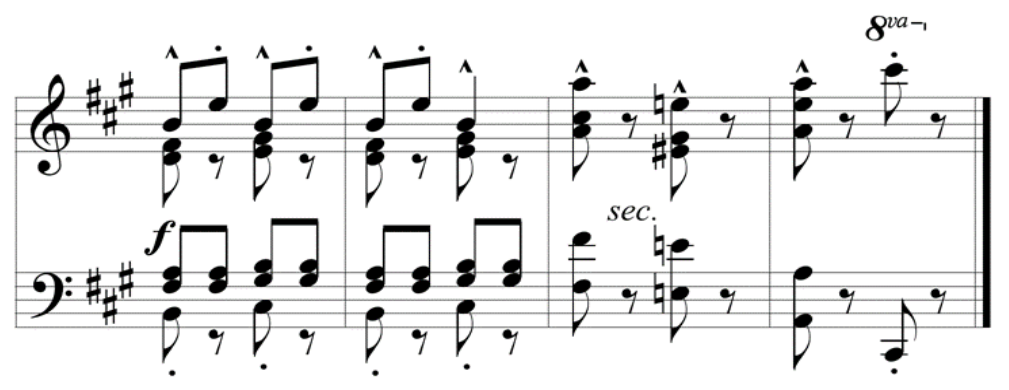

Figure 5. Auric: Prélude, Coda: mm. 60-63.

Prélude demonstrates the Satie-Cocteau aesthetics of simplicity and clarity, and it anticipates the recurring elements that permeate the collection, such as primacy of melody, balanced phrasal and formal structure, and the use of extended harmony, tonal ambiguity and bitonality. 


\section{"Romance sans Paroles" (1919) - Louis Durey}

Louis Durey (1888-1979) was a musical late-bloomer and a self-taught composer. Durey developed lifelong respect for Debussy after attending a performance of Pelléas et Mélisande in 1907, which had a profound impact on his musical aspirations. Other early influences included Renaissance polyphony, Arnold Schoenberg, and as one would expect from a member of Les Six - Erik Satie. He received his initial fame from L'offrande lyrique, Op. 4 (1914), a landmark in French music. ${ }^{44}$ His compositional career spanned 60 years and consisted of opuses numbering 116. His preferred genres were art song, choral setting and chamber music. His output for the piano is limited. One of his early important piano works is Carillons (1914) for four hands, which was premiered at the Vieux Colombier concert honoring Erik Satie in 1917. This concert, which also saw performances of Auric and Honegger, led to the christening of Les Noveaux Jeunes. Other piano works from this period includes Scenes de Cirque, Op. 9 (1917) and 3 Préludes, Op. 26 (1920).

"Romance sans Paroles" is perhaps the most sophisticated, thoughtfully designed, and pianistic work of the Album. It is dedicated to Ricardo Viñes, a prominent pianist and an ardent supporter of new music. This descriptive piece skillfully combines modality and romantic tendencies by integrating modes, parallel dyads and triads, chromaticism and orchestral grandeur. Written without a key signature, it includes tuneful and folklike melodies. It consists of seven sections with three contrasting pieces of material. Sections are separated by their distinctive meters, tonal centers, and textures. The piece includes two meters: $3 / 8$ and 2/8, and three tonal centers: F\#, D, and B. This analysis of tonal centers is predominantly determined by

\footnotetext{
${ }^{44}$ L'offrande lyrique, Op. 4 (1914) is a song cycle based on Gitanjali, a collection of poems, by Rabindranath Tagore, an Indian literary figure who won the Nobel Prize for the work in 1913. Durey includes the French translation by André Gide for the work.
} 
the melody; the accompaniment sometimes projects a conflicting tonality, demonstrating bitonality. The texture includes melody with accompaniment (in syncopated oom-pah-pah-pah style), and two and three parts, often incorporating ostinato. The work primarily includes a unique phrase structure grounded by a three-measure unit, plus occasional additional four- and six-measure units. The form of the piece, which can be considered a compact seven-part rondo, is:

$\begin{array}{lc}\text { Section A } & \mathrm{mm} .1-12 \\ \text { Section B } & \mathrm{mm} .13-28 \\ \text { Section A } & \mathrm{mm} .29-34 \\ \text { Section C } & \mathrm{mm} .35-46 \\ \text { Section } \mathrm{A}^{2} & \mathrm{~mm} .47-58 \\ \text { Section } \mathrm{B}^{1} & \mathrm{~mm} .59-74 \\ \text { Section } \mathrm{A}^{3} / \text { Coda } & \mathrm{mm} .75-89\end{array}$

Section A provides a recurring tuneful theme in a three-measure unit. This section is further divided into two subsections: the first subsection (Figure 6: mm. 1-6) states the opening theme in $\mathrm{F} \#$ minor in the top voice. By contrast, the second subsection (Figure 7: mm. 7-12) repeats the same theme in $\mathrm{D}$ minor in the lowest voice, with staccato articulation. Although the initial section is blurred by extra notes, both use the natural minor scale (Aeolian mode). This section incorporates the melody-and-accompaniment texture. 


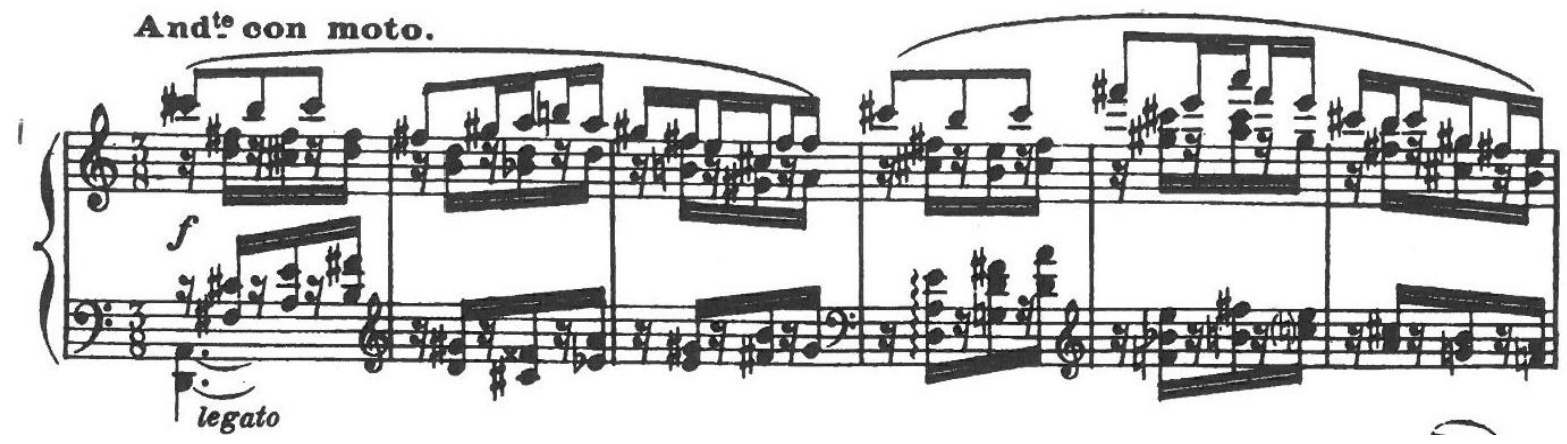

Figure 6. Durey: "Romance sans Paroles," Section I, mm. 1-6.

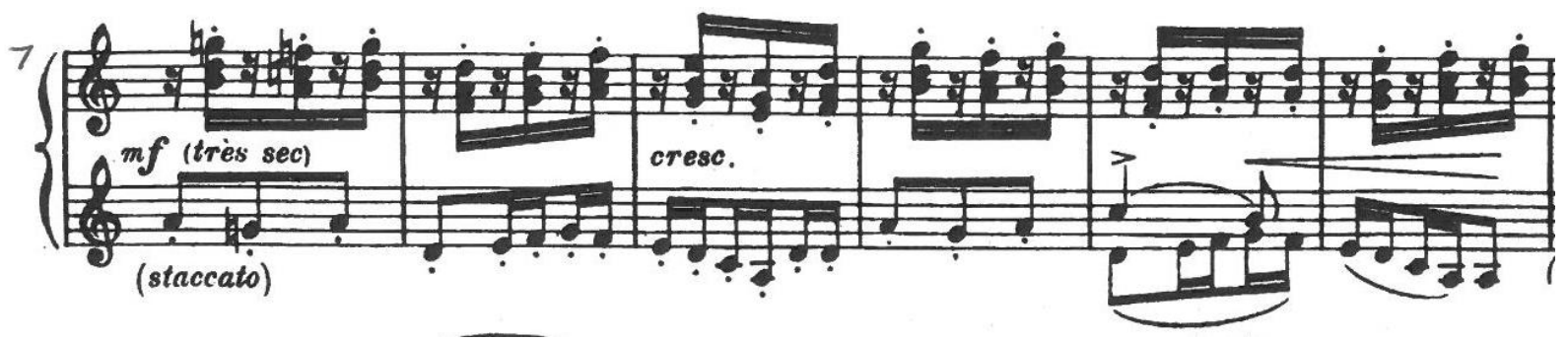

Figure 7. Durey: “Romance sans Paroles," Section I, mm. 7-12.

The accompaniment includes chromaticism, extended chords, parallel triads (mm. 7-12 in the right hand), and dyads involving 5ths, 4ths and 3rds in mm. 1, 2 and 6 respectively in the left hand. This accompaniment consistently and deliberately blurs the melody's well-formed tonality. Despite this, the underlying basic harmonic scheme supports the tuneful melody, which sounds like a café song accompanied by a jazz band. The first subsection opens with DM7 chordal accompaniment over a drone bass of D-A. The harmonic foundation of this subsection can be viewed broadly as: DM7-G\#dim7-E(9)-DM7-AM7-A7, with one harmony for each measure. With the added notes in the chords, this subsection consistently provides the intervallic clashing of 2 nds, both major and minor 2 nds, either in accompaniment or in combination with the melody. The second subsection draws accompanying parallel triads in the right hand from the prevailing mode. The melody and accompanying chords' top notes include the clash of the 2nds. Thus, the dissonance of the 2 nds is an important feature of this piece. 
Play the opening theme like an expressive song with the natural dynamic inflection. The first subsection involves a busy texture in the right hand: playing both melody and accompaniment. Maintaining a smooth and connected line without blurring the melody requires quick finger substitutions and effective pedaling. Since Durey's pedal marks are limited and without release instructions, additional decisions are necessary. As a general suggestion, use shallow pedaling and change frequently: that is, one pedal for each change of harmony. More specifically, at m. 1, use pedal for whole measure to incorporate DM7, and afterwards, pedal once per eighth note. Play the second subsection pointed and secco without pedal to project the contrasting articulation of molto staccato (marked tres sec [plus] staccato) with dynamic inflection and gentle phrase shaping. Make the right hand soft and bouncy. Bring out the subtle change of legato in mm. 11-12 in the left hand.

The thematic material of sections A, B and C are related. Section B shifts meters between $3 / 8$ and $2 / 8$, and incorporates three-, four- and six-measure units. It also includes consistent parallel dyads of 5ths and 4ths, recalling the left hand accompaniment of mm. 1-2. The texture is thin and includes three parts before concluding in two ( $\mathrm{mm} .23-28)$. The top line provides the melody over the ostinato dyads of 4ths in the bottom part.

The first two phrases (mm. 13-18) give a strong sense of modality due to the incorporation of the D Dorian over the parallel $5^{\text {th }} \mathrm{s}$ and $4^{\text {th }} \mathrm{s}$. The next phrase (mm. 19-22) retains the parallel dyads, but suggests both the D natural and harmonic minor scales in mm. 19-20 and 21-22 respectively (note: $\mathrm{mm} .21-22$ includes $\mathrm{C} \#)$. This phrase (mm. 19-22) also provides the first four-measure unit. The concluding phrase of this section (mm. 23-28) is a six-measure unit and spans over two octaves using D natural minor scale, which abruptly ends in m. 27 in high A. It is followed in $\mathrm{m} .28$ by a cadence that suggests a tonal center of C, punctuated by [Sol-Do] G- 
C, in the melody, supported by FM7 and Dm7. The combination of all notes of m. 28 constitute the D minor and C major triads (D-F-A-C-E-G) or Dm11, recalling the melody-accompaniment tonal combination of mm. 7-12. Thus, this modal section ends ambiguously.

Since section B starts on the subito piano following upon the previous crescendo, add a slight ritardando at the end of m. 12, and make a small space in order to drop the dynamic and to place the grace note before the downbeat of $\mathrm{m}$. 13. Hold the grace note with pedal. Play mm. 2324 without pedal (sans pedal) to project a staccato articulation over a smooth and connected line. The pedal marking in the middle of $\mathrm{m} .24$ is a print error. ${ }^{45}$ Lightly pedal just the downbeat of $\mathrm{m}$. 25. Use pedal sparingly in $\mathrm{mm}$. $26-28$ to avoid blurring the ascending line. Start mm. $23-28$ softly and crescendo slowly. Broaden mm. 27-28 considerably, since otherwise the abrupt ending of the melody can be quite disconcerting.

Section B is followed by a partial return of section A, mm. 29-34, which includes the D\# note in the melody in $\mathrm{m}$. 33. This inclusion employs F\# Dorian. The texture is in three voices of mostly single notes, except in $\mathrm{mm}$. 33-34, in which the middle and low voices recall the clashing 2nds from the opening and provide dissonant "wrong chords" over a tuneful melody. The harmonic design centers around A, E and B, contrary to the firm tonality of the melody. Play this section without pedal in similar manner as the opening.

Section $\mathrm{C}$ includes a distinctive periodic theme in a narrow range over a descending fournote ostinato; the prevailing tonal implication is $\mathrm{F} \#$ natural minor. This section consists of duple meter and two six-measure units (that is, $2 \times 3$ ); the second unit is a repetition an octave below. At m. 40 (Figure 8), a third voice appears briefly in the middle as a transition before continuing

\footnotetext{
${ }^{45}$ The articulation of the first two notes of left-hand in mm. 25-26 is identical, in which only m. 26 consists of pedal marking. The articulation of $\mathrm{m} .24$ can be executed effectively without the pedal. It seems the pedal marking in the middle of $m$. 24 should be placed at the downbeat of $m .25$ to make it consistent with m. 26 .
} 
with the two-part texture. Switch the middle and bottom parts; that is to play bottom and middle parts with the right and left hands respectively for ease and a smooth flow.

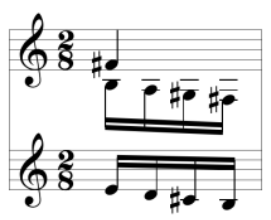

Figure 8. Durey: "Romance sans Paroles," Section C, m. 40.

The second phrase (mm. 41-46) concludes with an emphasis on the tonal center of $\mathrm{C} \#$ in mm. 45-46 by highlighting the [Sol-Do] v-i interval twice an octave apart. Emphasize the continuity between this section and the one that follows by broadening the last beat of $\mathrm{m} .46$; especially for those with small hands it is necessary to take the last B with the left hand. In addition, start a crescendo from m. 45 to prepare for the complete return of the section A material.

The return of the first subsection includes slight harmonic modifications but retains the basic progression and structure of chromatic dissonances, with parallel chords over a clear melody in the $\mathrm{F} \#$ Dorian ( $\mathrm{D} \#$ in $\mathrm{m} . \mathrm{51}$ ). The second subsection incorporates the $\mathrm{B}$ natural minor in the melody in the lowest part under an accompaniment of parallel triads, which includes all white notes except three instances of $\mathrm{F} \#$ to highlight the B-minor triad in $\mathrm{mm} .54$ and 58 .

This section concludes with a brief cadential suggestion of a tonal center of E; m. 58 emphasizes the v-i (B-E) interval in the bass voice. It also includes a small ritardando to lead to the complete return of the section B material. The return is nearly identical, with only small adjustments and variations, noticeable in mm. 61-62 and 64 in the left hand, which incorporates the $\mathrm{F} \#$ note. This minor change significantly transforms the tonality of the beginning two phrases (mm. 59-64), but the music still retains a modal quality, mainly due to the parallel dyads, despite 
the presence of all notes of the $\mathrm{G}$ major scale. The remaining phrases of this section (mm. 65-74) includes the earlier tonal design: again, with slight adjustments. It concludes with the combination chord of $\mathrm{C}-\mathrm{B} b$ majors (CEGBbDF) or $\mathrm{C} 11$ in $\mathrm{m} .74$, rather than the $\mathrm{Dm} 11$ of the earlier B section.

The final return of section A (Coda) is the climax of the piece, which is conceived orchestrally with triple forte. In this section, Durey introduces a counter-melody in the tenor voice (mm. 78-85) in F\# natural minor, whose concluding motif consists of four notes (Figure 9, highlighted in the score). This motif is repeated four times in the tonic and once in the dominant, recalling previous punctuation of the $\mathrm{v}-\mathrm{i}$ interval $(\mathrm{G} \#-\mathrm{C} \#)$ in $\mathrm{m}$. 84. The motif appears first in tenor (mm. 81-82) and then moves to the bass (mm. 82). A G\# half-diminished seventh harmony is emphasized in mm. $82-84$ by outlining it in dyads in the right hand, supported by separate eighth notes in the left hand, all over the motif in the bottom voice, before the conclusion of the piece in F\# minor. Furthermore, Durey adds a postlude of four measures in softer dynamics, which outlines the descending AM7 with added $6^{\text {th }}$ note. The piece ends on the DM7 chord, the same chord as the beginning. This cadence, familiar to pianists from the Ravel Sonatine, emphasizes ambiguity of tonality. This section incorporates a three-measure (75-77) and three four-measure units (mm. 78-89). 


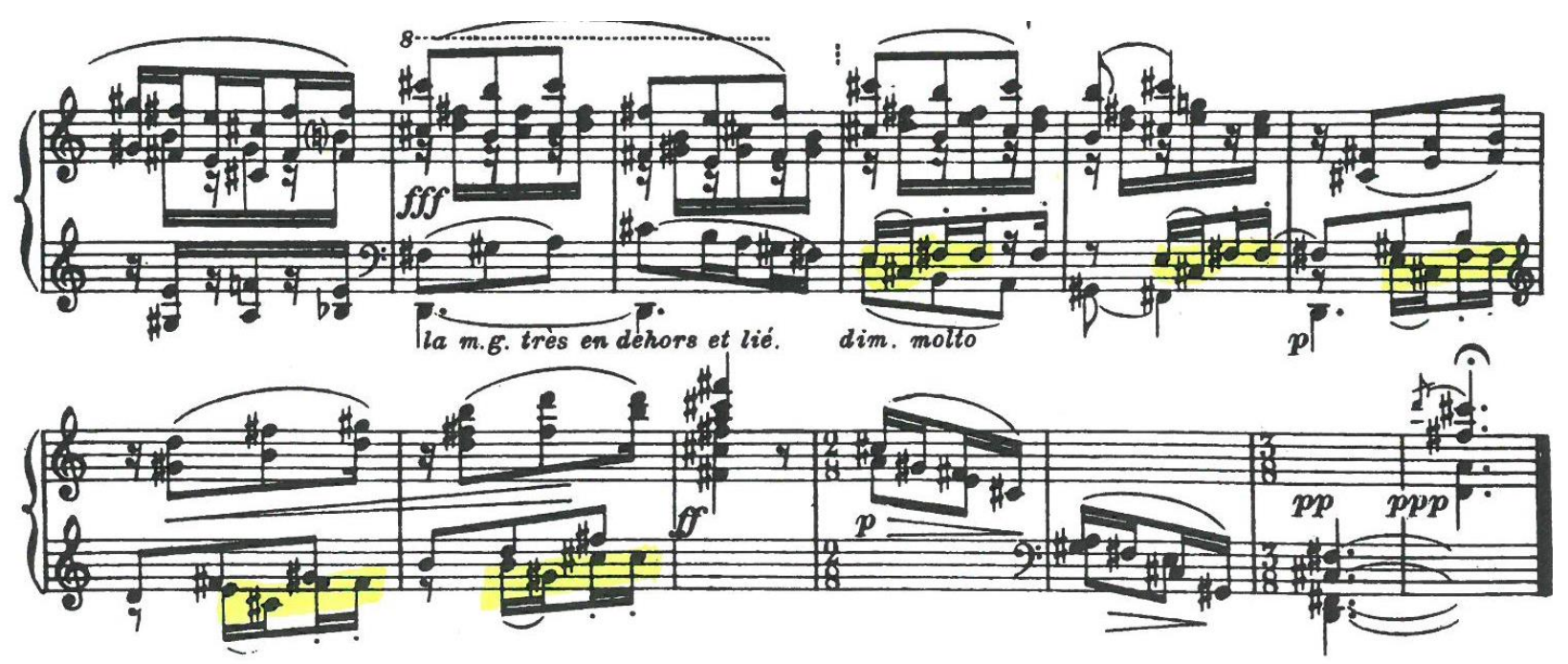

Figure 9. Durey: "Romance sans Paroles," Coda excerpt, mm. 77-89.

The last section requires orchestral grandeur and majestic sonority. Technically, it is the most challenging section, demanding big stretches to accommodate the octave melody and accompaniment which are combined in the right hand. Similarly, the left hand also plays two distinctive parts. Therefore, in order to project various melodic lines simultaneously without any blurriness, one needs both a careful and sensitive pedaling and quick finger substitutions. Experiment with flutter pedal to hold long bass notes in mm. 78-79 and 82 while still keeping melodic lines clean.

"Romance sans Paroles" is the most engaging piece in the Album. It is also the most romantic with its dynamic range, chromaticism and the descriptive title. Within the Album this is the work that puts the greatest importance on melody and sectional design. 


\section{Sarabande (1920) - Arthur Honegger}

Sarabande, composed in 1920, is the most contrasting piece of the Album with its strong linear tendency, which departs significantly from the Album's prevailing simplicity and tunefulness. Arthur Honegger (1892-1955), a dedicated contrapuntist, did not conform to the shared aesthetics of Les Six, but celebrated his friendships with the group members. His musical language is tonal with a highly individualized use of dissonance. He preferred larger orchestral forms. Consequently, despite his prolific musical output, he wrote few piano works. His important early works for the instrument include Hommage à Ravel (1915), Toccata et variations (1916), and 7 pièces brèves (1919-1920).

Honegger integrates the characteristic triple meter of a Sarabande throughout and demonstrates its characteristic accent by frequently emphasizing the second beat with the dotted rhythm. The tonality is centered on $\mathrm{Bb}$ although the key signature only includes one flat, suggesting $\mathrm{Bb}$ Lydian. The work includes some regular features of the set such as harmonic ambiguity and balanced phrase structure, non-functional chords and four-measure units. The work consists of two sections plus the return of the first with slight modification. While the first section ends ambiguously without a strong cadence, the second section prepares the return with a dominant $7^{\text {th }}$ harmony and a leading tone in addition to a ritardando. Its form, in sum, is:

$\begin{array}{ll}\text { Section A } & \text { mm. 1-8 } \\ \text { Section B } & \text { mm. 9-18 } \\ \text { Section A } & \text { mm. 19-26 }\end{array}$

Section A opens with an angular theme, consisting (except in m. 7) of a single line over a non-functional harmony organized through chromatic and other stepwise motion, demonstrating a strong linear tendency (Figure 10). The opening theme starts on the notes $\mathrm{Bb}$ and $\mathrm{D}$ in the first 
and second phrases respectively in $\mathrm{mm} .1$ and 5. The section ends ambiguously without a strong cadence. Furthermore, the bass, an $\mathrm{F}$ dotted quarter note, does not establish its dominant function in $\mathrm{m} .8$ since it does not proceed to a $\mathrm{Bb}$.

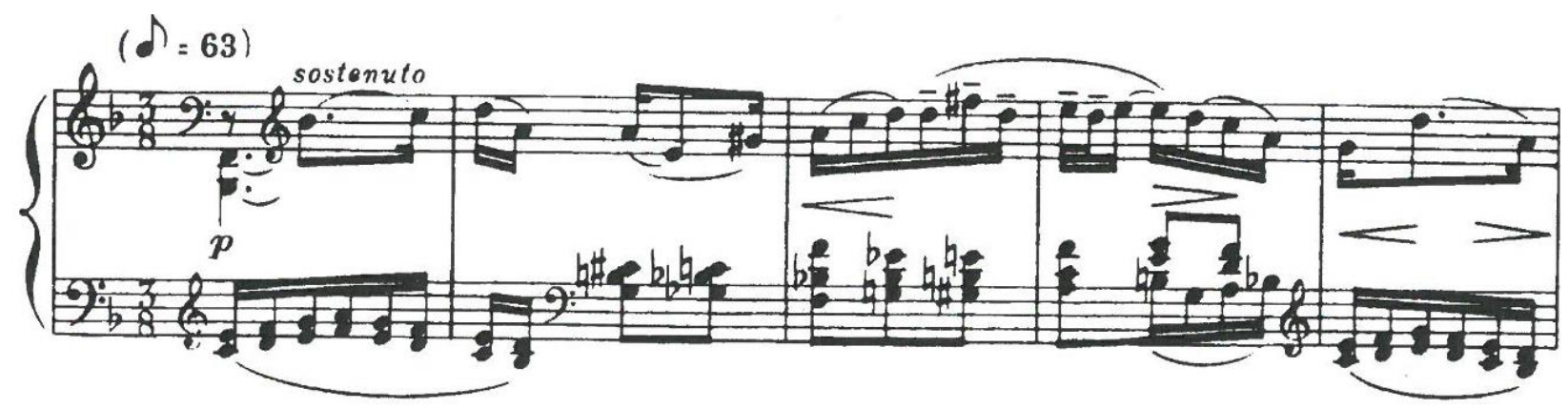

Figure 10. Honegger: Sarabande, Section A excerpts, mm. 1-5.

This piece is conceived orchestrally. Specifically, and creating one of the most challenging issues in this section - and, indeed, in later sections - are the passages with 3rds, 4ths and 5ths in quick rhythm. These passages are molto legato and require evenness; therefore, a combination of careful fingering and sensitive pedaling is essential to project the linear lines. As a general suggestion in such passages, even if connecting both moving lines is unrealistic, connect at least one to give an illusion of legato. In section A, play both the right and left hand parts prominently with gentle phrase shaping. The rich resonance of the dotted quarter note drone bass of $\mathrm{Bb}-\mathrm{F}$ under the stepwise movement of the 3rds poses a particular problem. In $\mathrm{m}$. 1, use a half pedal for the whole bar to retain the bass, while bringing out the other parts prominently as much as possible over the blurriness. Use this technique appropriately later in the piece, in similar passages including those involving running double notes. At m. 8, play the top three notes of the left hand, highlighted in the score by the right hand (Figure 11). Note that 
Figure 11 also suggests hand redistribution for the left hand and fingering for the right hand (m.

$11)$.

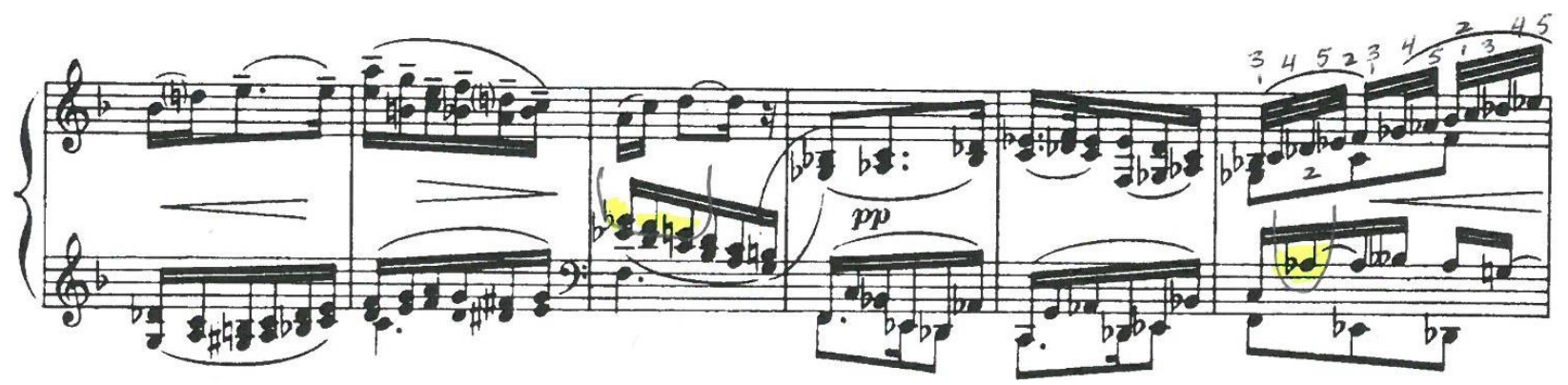

Figure 11. Honegger: Sarabande, Section A-B excerpts, mm. 6-11.

Section B opens with $\mathrm{Gb}$ and $\mathrm{F}$ tonal centers in the right and left hand respectively in

mm. 9-12. Mm. 9-11 exclusively use the notes of $\mathrm{Db}$ major scale except $\mathrm{B} b \mathrm{~b}$ and $\mathrm{G}$ in $\mathrm{m}$. 11. The section then continues with chromaticism from $\mathrm{m}$. 12. The texture is mostly four parts with the bass moving primarily stepwise; the bass leap in $\mathrm{mm} .14$ and 16 can be viewed as an octave substitution. The bass provides a strong harmonic foundation for the thematic line of the top voice. The middle voice provides angular chromatic interest. Despite strong linear tendencies, this section is evocative of jazz harmonies, particularly in mm. 12-16. The last phrase of this section (mm. 13-18) includes a phrase extension of two measures, creating the only six-measure unit of the piece. This phrase is also modulatory with emphasis on E, A and D tonal centers in mm. 13-15 respectively before highlighting V-I-V7 in $\mathrm{mm}$. 16-18. Thus, the section concludes strongly in the $\mathrm{V} 7$ of $\mathrm{Bb}$ and leads to the return of section $\mathrm{A}$ in $\mathrm{m} .19$.

Maintaining clear lines involving wide intervallic spans is not only challenging, but also unrealistic here. Figure 12 suggests some hand redistribution in mm. 13, 15 and 17. Use roll chords and jumps, when required, in conjunction with rubato, appropriately to maintain as smooth a line as possible. 


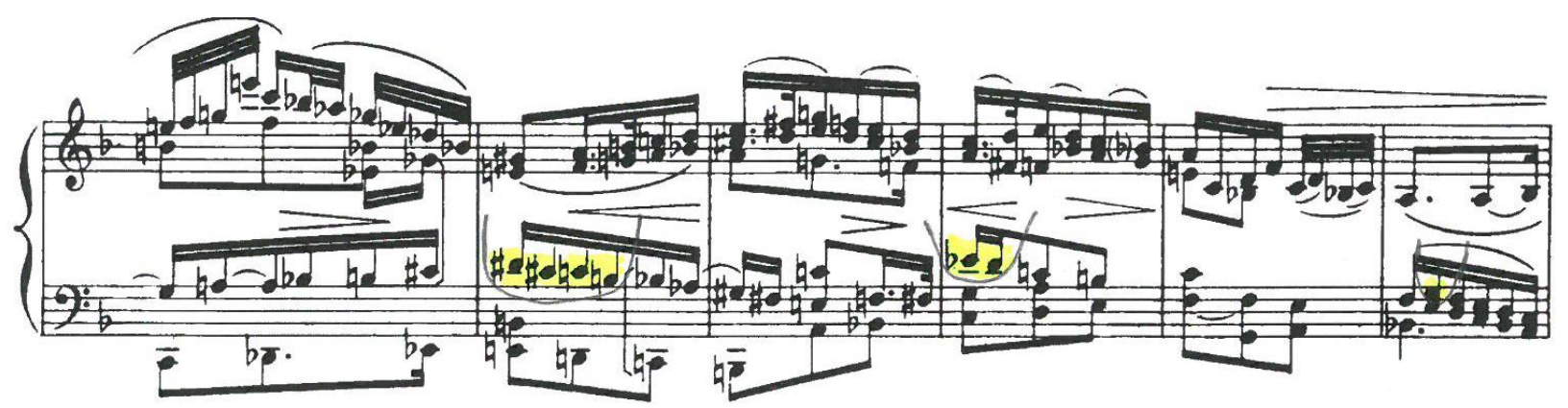

Figure 12. Honegger: Sarabande, Section B excerpts, mm. 12-17.

The return of section A includes the identical melody, except the last three measures, over a modified accompaniment texture of $3 \mathrm{rds}$, 4 ths and 5 ths in a continuous $32^{\text {nd }}$-note rhythm. This section demonstrates the underlying harmony more transparently by incorporating its skeletal notes within the running accompaniment texture. This section also ends convincingly in $\mathrm{Bb}$. The final chord includes $\mathrm{B} b, \mathrm{~F}, \mathrm{C}$ and $\mathrm{E}$ notes, which recalls the opening chord, rendering the start and end identical.

Sarabande offers some of the most interesting textures in the set, although its unpianistic style might be a barrier to a younger pianist. The piece starts ambiguously, but clearly arrives at the tonic of $\mathrm{Bb}$. 


\section{$\underline{\text { Mazurka (1914) - Darius Milhaud }}$}

Darius Milhaud (1892-1974) displayed musical aptitude at an early age, growing up in a musical environment; both his parents were amateur musicians. Milhaud admired Debussy throughout his life. In 1905 while studying Debussy's string quartet, Milhaud developed a great respect for Debussy which left a significant impact on the young composer. ${ }^{46}$ Mazurka was written considerably before the other pieces of the Album: in 1914. It shows some Debussy influences such as non-functional harmony and parallel chords. It was composed during Milhaud's student years at the Paris Conservatoire, and before his diplomatic appointment in Brazil. ${ }^{47}$ Milhaud traveled extensively throughout his life and incorporated folk melodies and rhythms in his post-World War I music. Besides the Brazilian rhythms, the folk influences also included polytonality and polymodality. Jazz also had a profound influence on Milhaud; his early encounter with the genre occurred on his return to Paris from Brazil via New York in 1918. Despite his prolific output (he completed 443 numbered opuses) Milhaud's piano output during 1910s is limited, numbering around half a dozen works, and mainly follows traditional forms such as suite, variations, and sonata. One of his important early piano works, Saudades do Brasil, Op. 67, was completed in 1921.

Mazurka is a short work written without a key signature and includes an ambiguous tonality. The beginning and ending include a D-major triad as a harmonic foundation. The melodic contour of the opening phrase (mm. 1-4) incorporates G melodic-minor scale with occasional flatted second note. The opening harmonic and melodic relationship therefore

\footnotetext{
${ }^{46}$ Milhaud played second violin in the quartet of his teacher, Léo Bruguier, and studied Debussy's string quartet in 1905.

${ }^{47}$ Milhaud served as an administrative assistant to the French foreign ministry in Brazil for two years, 1916-18, under Paul Claudel, playwright, poet and dramatist.
} 
suggests the tonal center of $\mathrm{G}$ minor, with the opening and closing triad functioning as a dominant. However, the piece does not include any $\mathrm{G}$ minor triad. The time signature is mistakenly published as a common meter without any textural explanation and is clearly in a slow triple meter. Additionally, it does not provide any characteristic elements of Mazurka such as accent on the weaker beats. Its thin texture aligns with the simplicity of Satie's Gymnopédies, and consists of mostly melody and accompaniment with occasional third voice. It incorporates balanced phrase structure of mostly four-measure units, except one five-measure unit and two six-measure units. This piece has four sections: A, B, $\mathrm{A}^{1}$ and coda. Section $\mathrm{B}$ is relatively brief and distinguishable due to its distinctive texture: outlining series of ninth chords and a fullydiminished seventh chord. The return of section A is preceded by rallentando and marked $M o u v^{t}$ du début (tempo primo). The form is:

$\begin{array}{lc}\text { Section A } & \text { mm. 1-17 } \\ \text { Section B } & \text { mm. 18-23 } \\ \text { Section A } & \text { mm. 24-33 } \\ \text { Coda } & \text { mm. 34-37 }\end{array}$

The opening four-measure theme provides a primary building block and appears seven times in various guises. This theme (Figure 13, mm. 1-4) incorporates the right-hand melodic contour with scalar texture in $\mathrm{G}$ melodic-minor scale with a flatted $2^{\text {nd }}$ accidental $(\mathrm{Ab})$ in $\mathrm{mm} .1$ and 3. Over this scale, the left hand accompaniment provides parallel chords, alternating between D7 and C7. The second phrase (mm. 5-8) introduces a new middle voice which restates the opening theme with slight modification. This phrase does not borrow harmonic ideas of the first, and mostly uses A major (or A7) for three measures before using C $¥$-major chord. The melodic lines in middle and top voices include mostly the whole-tone scale in A before culminating the 
phrase in $\mathrm{m} .8$ with the $\mathrm{C} \#$-major scale, emphasizing the common pitch material between the two scales: that is, $\mathrm{C} \#, \mathrm{D} \#, \mathrm{E} \#$. The third phrase (mm. 9-12) also includes the modified opening theme in bass. Here, the ascending G melodic-minor scale is used mostly, incorporated even in the descending line (mm. 9-12). The concluding phrase (mm. 13-17, Figure 14) integrates the only five-measure unit. The hemiola (mm. 14-15) gives forward motion and makes animez un peu effective before the right hand ascends with a $\mathrm{G}$ melodic-minor scale.

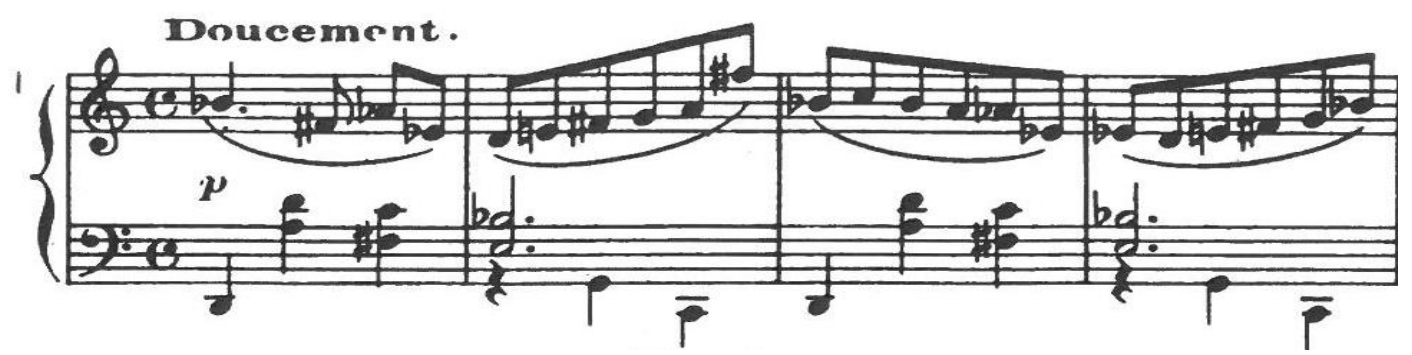

Figure 13. Milhaud: Mazurka, opening theme/phrase, mm. 1-4.

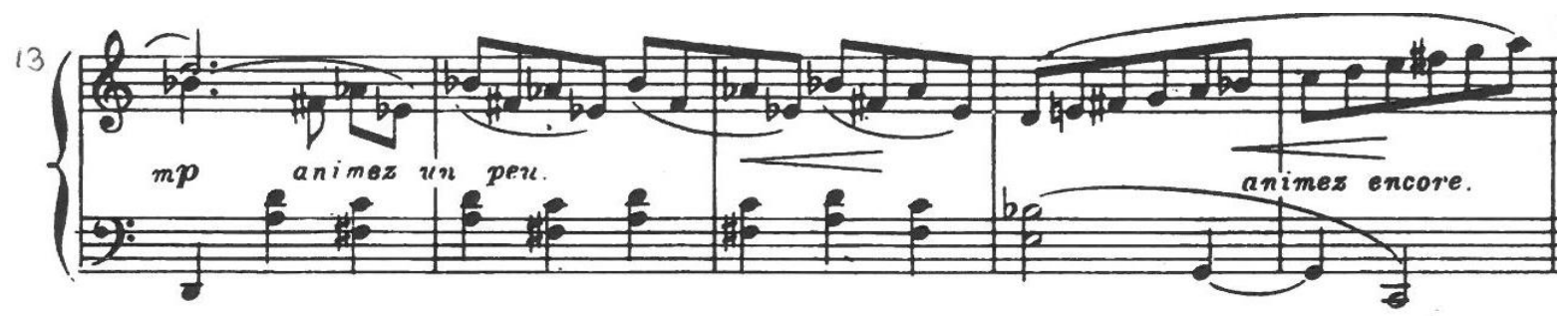

Figure 14. Milhaud: Mazurka, Section A, mm. 13-17

Section A includes a limited dynamic range: $p, m p$ and $p p$. The section integrates a balanced phrase structure of four-measure units. When performing the opening phrase (mm. 14), subdivide the phrase in two two-measure units, and make the last beat of the second measure the peak within the softer context. Since the piece restates this theme several times, maintain this basic phrase shaping and incorporate Milhaud's additional dynamic markings. There is a threevoice texture in mm. 5-8. Quick finger substitution and effective pedaling are requisite here in order to maintain smooth lines. In m. 5, take the B and the second $\mathrm{C} \#$ with the left hand (Figure 15). Use shallow pedaling throughout this section, generally one per bar and more frequent 
changes when possible. Rolling of the chord encompassing a $9^{\text {th }}$ may be necessary for smaller hands in $\mathrm{m}$. 9. Start the roll slightly before the beat, and place the top note on the beat. Use rubato at the end of the phrase in $\mathrm{m} .8$ in conjunction with the printed cedez (slower) to adjust the timing. At the concluding phrase of section A (mm. 13-17), start softly and crescendo gradually, highlighting the hemiola in mm. 14-15. This whole section A can also be viewed as two big units: mm. 1-8 and 9-17. In this broad point of view, make m. 6 the highest point of mm. 1-8. The climactic point for mm. 9-17 is in m. 17, which leads to the first highest note of the piece in m. 18 .

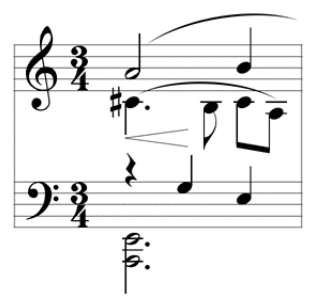

Figure 15. Milhaud: Mazurka, Section A, m. 5.

Section B (mm. 18-23) is brief and provides outlining of parallel $9^{\text {th }}$ harmony: five chords - one per bar. The bass moves up a minor third, starting with $\mathrm{E}$, then to $\mathrm{G}, \mathrm{B}$, and $\mathrm{C \# \text {,and }}$ concludes suggesting $\mathrm{Bb}$ minor tonal center. On the other hand, top voice moves down by major sixths; $\mathrm{B} b, \mathrm{C} \#, \mathrm{E}, \mathrm{G}$ and $\mathrm{B} b$ - this combination constitutes a fully-diminished seventh chord. In addition to the rallentando marking in $\mathrm{m}$. 20, Milhaud further slows down the concluding section by explicitly writing a quintolets in $\mathrm{m}$. 23 . This section includes the first six-measure phrase. Use full pedal for each harmony (that is, each measure) to make this section sonorous. 


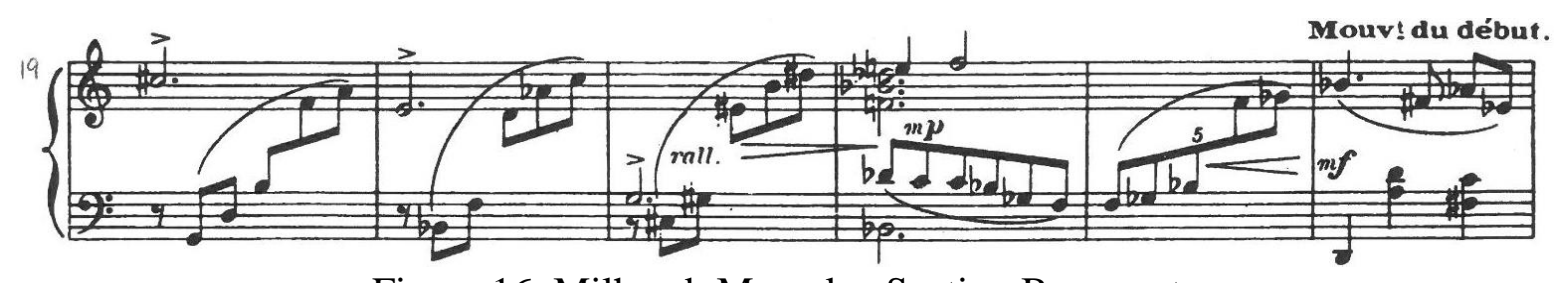

Figure 16. Milhaud: Mazurka, Section B excerpt.

The return of section A begins by restating the opening phrase (mm. 1-4) exactly in relatively louder dynamics; mezzo forte rather than the previous piano. The second phrase (mm. 28-33), which is a second six-measure unit, repeats the opening phrase down a half step, which is unexpected, accompanied by subito piano following upon the previous crescendo. Make a small space before dropping the dynamic significantly in $\mathrm{m} .28$ (Figure 17) to project this surprise and to allow the sound of previous high volume to clear. This phrase extends two measures of ascending $\mathrm{G}$ melodic-minor scale (mm. 32-33) or the whole-tone scale in $\mathrm{Bb}$ : the ambiguity is due to the absence of $\mathrm{A}$ or $\mathrm{Ab}$.

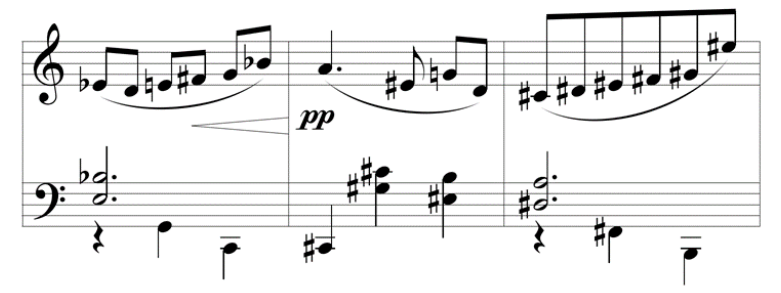

Figure 17. Milhaud: Mazurka, Section A ${ }^{1}$ excerpt, mm.27-29.

The coda (Figure 19, mm. 34-37) emphasizes the opening motif from mm. 1 and 2. It poses rhythmic challenges in $\mathrm{m}$. 35 . Since the tempo is slow, internalizing the underlying $16^{\text {th }}$ note rhythm helps to execute $\mathrm{m} .35$ : three $16^{\text {th }}$ notes for each note of the right hand. Certain students would benefit from having this rhythm renotated in a way that makes the placement of the quarter notes clear (Figure 18). 


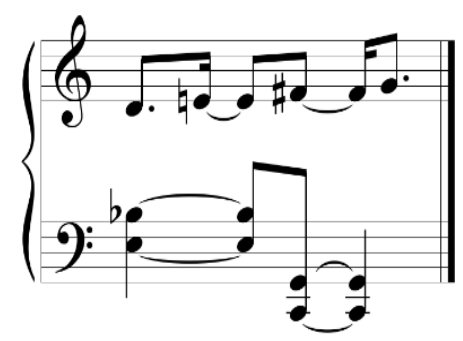

Figure 18. Renotated m. 35 of Milhaud's Mazurka.

At m. 36, Milhaud suggests both D major and minor tonalities: the middle voices clearly show D-natural minor scale, while the top voice repeats the opening motif, with its F\#, all over a drone bass of D-A. Two arguments can be made regarding this drone with its tie-slur in $\mathrm{m}$. 36; either it carries over to $\mathrm{m}$. 37 , in which case the ending will be muddy and dissonant, or the slur does not carry over since it does not cover the bar line (Figure 19) and the piece ends on D-major triad in the first inversion. The performer must make the ultimate decision.

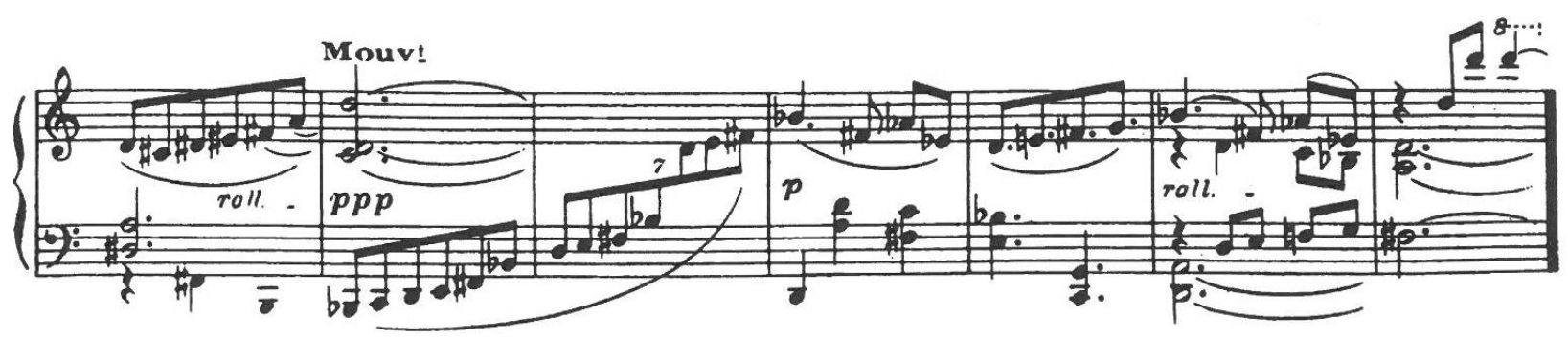

Figure 19. Milhaud: Mazurka, mm. 31-37. 


\section{"Valse in C" (1919) - Francis Poulenc}

"Valse in C," written in 1919, is the most representative work of the Satie-Cocteau aesthetics from the Album with its directness, simplicity and clarity. Francis Poulenc (18991963) maintained these stylistic traits in piano writing throughout his career. His piano output is considerably large, and his early works consist of elegant salon pieces such as Trois Pastorales (1917), Suite in C (1920) and Six Impromptus (1920-21). Poulenc received early and immediate success with his piano composition, Trois Mouvements Perpétuels, in 1918. The work was premiered at the Lyre et Palette by Ricardo Viñes, who was not only a champion of contemporary music, but also Poulenc's piano teacher and mentor. This concert also included works by Auric, Durey, Honegger, Milhaud and Tailleferre.

Valse is a lively, unpretentious and repetitive piece, whose simplicity and predictability show the popular musical style of the music hall and the cafe. Its texture is a single line melody over an accompaniment in triple meter in the oom-pah-pah style. Both the melody and harmony include the tonality of $\mathrm{C}$, latter mostly using the tonic and dominant with occasional circle-of5ths progression (i.e., mm. 33-40, 105-112). The piece includes balanced and periodic phrase structure of four-measure units with a light sub-division into two-measure units in the middle. The piece integrates both percussive and lyrical style. It consists of two contrasting sections, both repeated with slight modification. The sections feature distinctive modal or tonal design. The first section can be subdivided into four small subsections. Its form can be summarized as: 
Section A

mm. 1-44

a

b

$a^{1}$

c

transition mm. 1-16

mm. 17-24

mm. 25-32

mm. 33-40

mm. 41-44
Section B

Section $A^{1}$

Section $\mathrm{B}^{1}$

Coda mm. 45-72

mm. 73-112

mm. 113-140

mm. 142-145

The whole section A is primarily built on periodic phrases incorporating the C Lydian scale over the tonic triad of $\mathrm{C}$ major. This design is first interrupted by hemiola, subsection (b), emphasizing either the flatted $2^{\text {nd }}$ dissonance (mm. 17-18 and 21-22) or the tonic triad (mm. 1920 and 23-24). The opening theme's conclusion, an ornamented descending line, provides a subtle underlying hemiola by emphasizing the tonic three times (Figure 20, mm. 7-8). Subsection (b) - (Figure 21, mm. 17-24), recalls this subdued hemiola with much prominence in fortissimo dynamic to interrupt the triple-meter pulse. The second interruption, subsection (c), provides much-needed relief from the monotonous tonic triad of 32 measures by offering harmonic interest in a descending circle of 5 ths progression. 


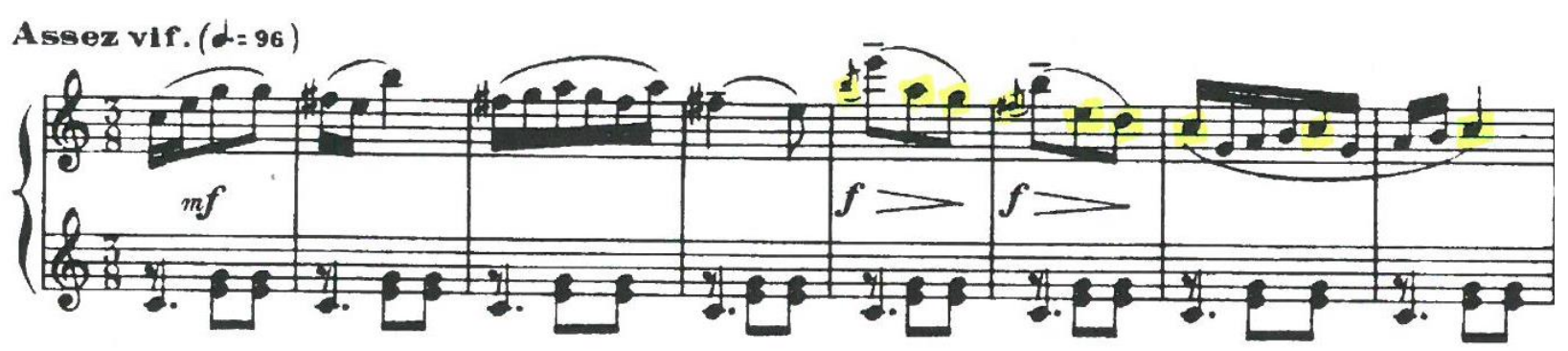

Figure 20. Poulenc: Valse, Section A excerpt, mm. 1-8.

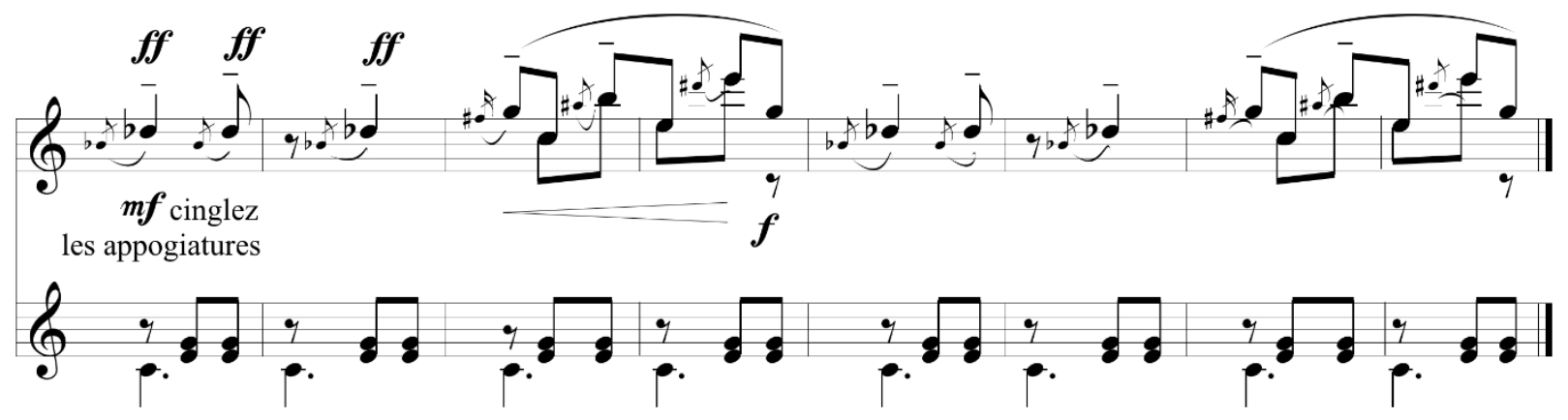

Figure 21. Poulenc: Valse, Subsection (b) excerpt, mm. 17-24.

The conclusion of the circle progression includes an interruption by a "wrong chord" in double-notes arpeggiation in mm. 36 and 40 (Figure 22). The chord consists of all the G wholetone scale plus a D note. This measure also interrupts the flow of the music through its unanticipated faster measure, marked presser, which disrupts the well-established pulse and gives impression of café jazz style of "vamp until ready." Make an extremely slight pause after m. 36 to interrupt the pulse.

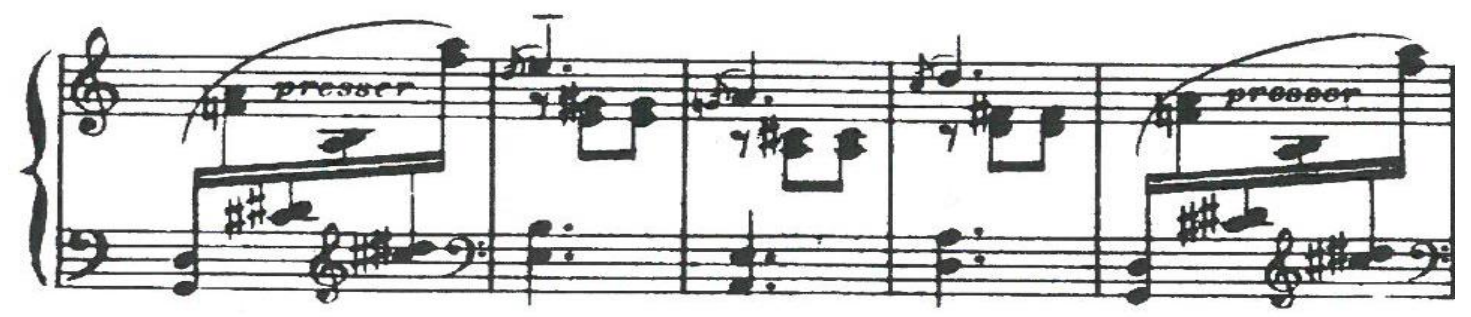

Figure 22. Poulenc: Valse, Subsection (c) excerpt, mm. 36-40. 
Make the opening phrase expressive with natural dynamic inflection. The hemiola sections should be pointed, brassy and percussive. An inclusion of a septolet in $\mathrm{m} .31$ pose a slight challenge to coordinate with the accompaniment. An effective approach may be to subdivide the septolet as 2-3-2 rather than 7 equal notes, and execute it tastefully; that is, play with slight broadening within the strict pulse and without making the subdivisions obvious (Figure 23). The descending line (mm. 41-44) forms a smooth transition between sections A and B. Play the grace notes in m. 42 as the sixteenth note triplet on the second eighth note of the measure, in combination with the principle note, C (Figure 24).

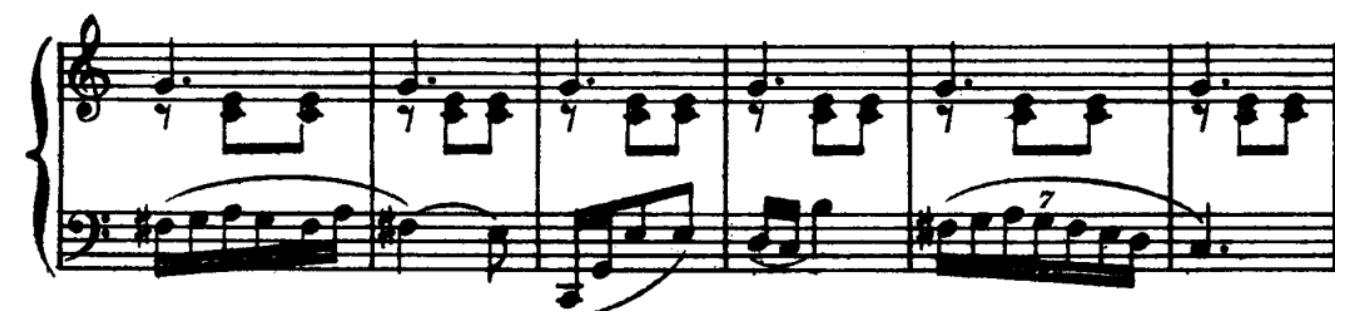

Figure 23. Poulenc: Valse, Subsection $\left(\mathrm{a}^{1}\right)$ excerpt, mm. 27-32.

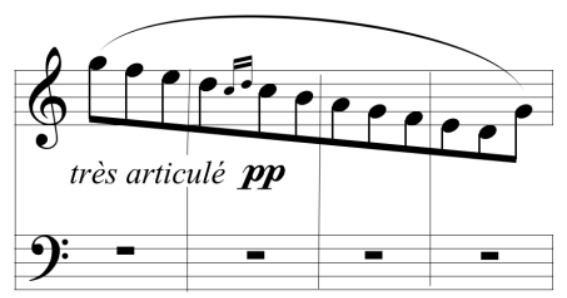

Figure 24. Poulenc: Valse, Subsection (c) excerpt, mm. 41-44.

Section B is also deliberately repetitive, alternating between tonic and dominant in the left hand. Over this monotonous circus-like harmonic foundation, the right hand provides a rudimentary melodic line in octaves with a narrow range as well as a partial accompaniment, "pah-pah." The coda of section B (mm. 65-72), includes the only two-measure unit; the duple use of this unit combines to form larger units of 4 and 8 measures. Furthermore, two "wrong 
chords": A\# diminished and $\mathrm{D} \#$ minor add a slight spiciness in this otherwise extremely monotonous section.

The très chanté (mm. 45-64 et passim) presents special problems of touch. Make the right-hand fingers crawl on the keys with a loose wrist and relaxed arms to play the melody expressively and prominently with a soft accompaniment. In mm. 65-72, by contrast, make the right-hand fingers firm and pointed.

At mm. 105-112 ( $\mathrm{c}^{1}$ of $\left.\mathrm{A}^{1}\right)$, Poulenc adds a counter-melodic line with a très chanté mark. At the intervallic span of $12^{\text {th }}$, which is too big a stretch for most, in mm. 106 and 110 , roll the left hand and play the bass A on the downbeat (Figure 25). Alternatively, it might be appropriate to treat the bass A and tenor $\mathrm{E}$ as two sixteenth notes since the tempo is relatively fast. This will make a slight interruption in the melody. These are the only awkward passages in this otherwise highly pianistic piece. At mm. 108 and 112, take the tenor notes with the right-hand thumb. If the $9^{\text {th }}$ is too big a stretch, approach it like mm. 106 and 110. The last septuplet in m. 144 is in unison in both hands. Since it does not create a coordination problem between hands, play it evenly. It is also appropriate to play it rhythmically as in $\mathrm{m} .31$ for consistency. In order to get a strong ending and to add some humor, it is effective to add a slight pause before the final down beat. Figure 26 suggests fingering for m. 144:

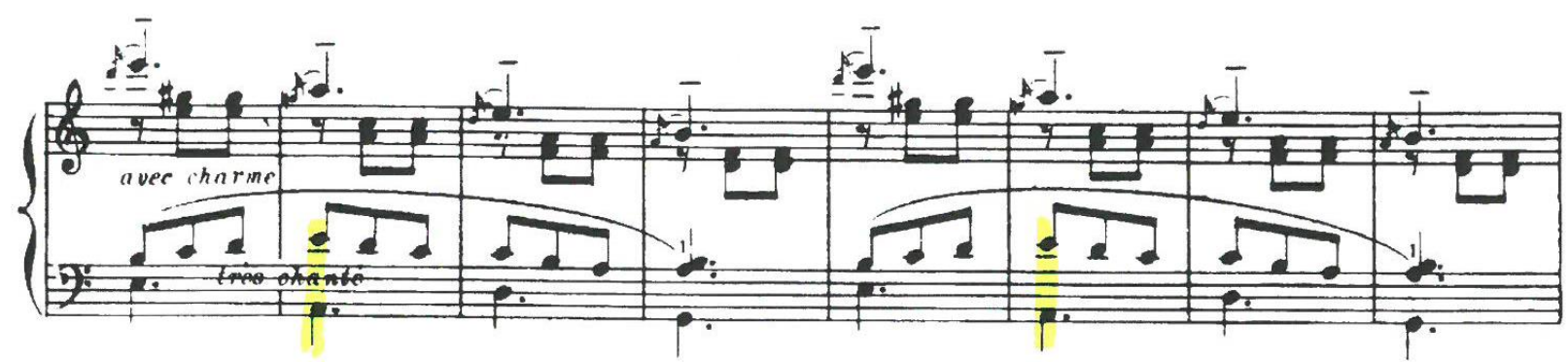

Figure 25. Poulenc: Valse, Section $\mathrm{A}^{1}$ excerpt, mm. 105-112. 


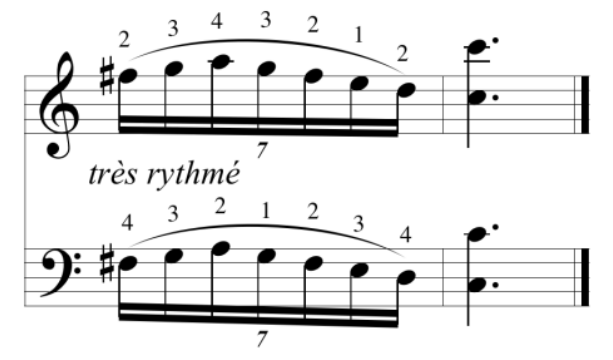

Figure 26. Poulenc: Valse, Ending: mm. 144-145.

This work demonstrates the fun, amusing and entertaining spirit of the music hall and the café. Its model draws inspiration from Satie's Gymnopédies with its lyrical melodic line, and clear and predictable phrase structure with many repeats over a deliberately simple chordal accompaniment. Scholars have both criticized and lauded Valse for its musical content. James Harding dismisses the piece by saying:

Poulenc was careless enough to allow his "Valse" to be printed. This mechanical little piece must have been the sort of thing he indulged in at the keyboard while looking for an idea, and it added nothing to his reputation. ${ }^{48}$

On the other hand, Maurice Hinson provides a contrasting view praising the style thus:

An endearing miniature full of echoes of the Parisian café concert, capturing in its few bars the feeling of a Toulouse-Lautrec painting. Composed when Poulenc was greatly influenced by Igor Stravinsky. This piece displays Stravinskian brittleness (wrong notes!) and is Poulenc's witty homage to this popular dance. Fetching tunes and rhythms. ${ }^{49}$

It should be noted that Valse's simplicity and clarity follow the new French artistic aspirations of the post war. The piece fits perfectly with the intention of the Album to project a specific concept; here, it is a distinctive new music.

\footnotetext{
${ }^{48}$ Harding, Ox on the Roof, 98.

${ }^{49}$ Hinson, Maurice, and Wesley Roberts. Guide to the Pianist's Repertoire. Fourth ed. Indiana Repertoire Guides. Bloomington: Indiana University Press, 2014.
} 


\section{Pastorale (1919) - Germaine Tailleferre}

Germaine Tailleferre (1892-1983), the only female member of Les Six, was a piano prodigy who won several awards in piano at the Paris Conservatoire. Her compositions during the 1910 s mostly included chamber music, frequently incorporating piano, such as the piano trio and the quintet. Her solo piano output consisted of mostly character pieces such as Impromptu (1912), Romance (1913) and Hommage à Debussy (1920). During this period, her two-piano works including Jeux de plein air particularly received appreciation and favorable reception. Erik Satie christened Tailleferre as his "musical daughter" after hearing the performance of Jeux de plein air in $1917 .{ }^{50} \mathrm{He}$ also promoted her as a member of Les Nouveaux Jeunes in the Parisian artistic events. $^{51}$

Pastorale, dedicated to Darius Milhaud and composed in 1919, is a pianistic, sectional, and through-composed work with a brief coda. The sections are distinctly marked with phrase endings often accompanied by ritardando, caesurae, and fermata. This short character piece incorporates complex meter and bitonality. The piece alternates between $5 / 8$ and 6/8 and concludes in 3/8. Each section includes a clear meter. Similarly, each new section consists of different bitonalities. The piece includes following sections:

\footnotetext{
${ }^{50}$ Orledge, Robert. 2001 "Tailleferre, Germaine." Grove Music Online.1 Apr. 2019. http://www.oxfordmusiconline.com/grovemusic/view/10.1093/gmo/9781561592630.001.0001/omo9781561592630-e-0000027390.

${ }^{51}$ In addition to Tailleferre, Les Nouveaux Jeunes included Auric, Durey and Honegger.
} 


$\begin{array}{lc}\text { Section I: } & \text { mm. 1-8 } \\ \text { Section II: } & \text { mm. 9-16 } \\ \text { Section III: } & \text { mm. 17-28 } \\ \text { Section IV: } & \text { mm. 29-36 } \\ \text { Section V: } & \text { mm. 37-48 } \\ \text { Coda: } & \text { mm. 49-53 }\end{array}$

Pastorale incorporates a balanced phrase structure consisting of either two-measure units (sections I and V) or four-measure units (sections II, III and IV). Despite the key signature suggesting D major, the tonality is ambiguous because of the consistent use of two tonalities; each hand plays different tonal centers. Melodic lines are either angular with the emphasis on the interval as in section I or tuneful and folk-like in sections II, III and IV. The last section, section V, mainly highlights the harmony: specifically, it combines tonal elements from previous sections. Pastorale does not provide any unaltered tonic triad. Rather, the harmony is blurred with added notes and the tonal centers changes abruptly from one section to another. As noted, Tailleferre provides important dynamic markings to project contrasting sections. However, the dynamics within sections are limited. Effective phrase shaping, therefore, must be gentle, but can be achieved by following two general ideas:

1) In the two-measure unit, approach the beginning of the second measure as a high point.

2) In the four-measure unit, make the second half of the third measure the peak.

Dynamics of the piece are mostly on the softer side, hovering between piano and mezzo forte. The climactic and loudest point, marked forte, is in $\mathrm{mm} .25-26$.

Section I starts with the dissonant texture of four-note modes suggesting D major and F\# major in left and right hands respectively, with the former arpeggiating only white notes and the 


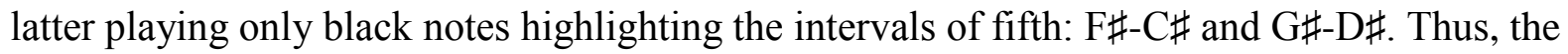
opening shows a white-key/black-key bitonality (Figure 27). Additionally, the opening perpetual motion with its right hand in constant eighth- and left in sixteenth-note rhythm, creates a busy yet playful atmosphere complementing the tempo and mood marking: Enjoue (playful). As recommendations for performance, start the opening phrase (mm. 1-2) softly, as a two-measure unit, with dynamic inflection leading to the downbeat of $\mathrm{m}$. 2. In mm. 5-8, Tailleferre adds a third line, an alto voice, which imitates the soprano line. The right hand here strongly suggests A major tonality, while left hand retains the D major. The section concludes on A major, dominant of the implied tonality, followed by a fermata. In $\mathrm{m}$. 7, use the left hand to play the highlighted B and $\mathrm{C \# .} \mathrm{In} \mathrm{m.} \mathrm{8,} \mathrm{consider} \mathrm{the} \mathrm{extra} \mathrm{eighth} \mathrm{note} \mathrm{to} \mathrm{be} \mathrm{a} \mathrm{metric} \mathrm{augmentation,} \mathrm{and} \mathrm{add} \mathrm{a} \mathrm{slight}$ ritardando before having a brief, but complete, silence on the fermata.

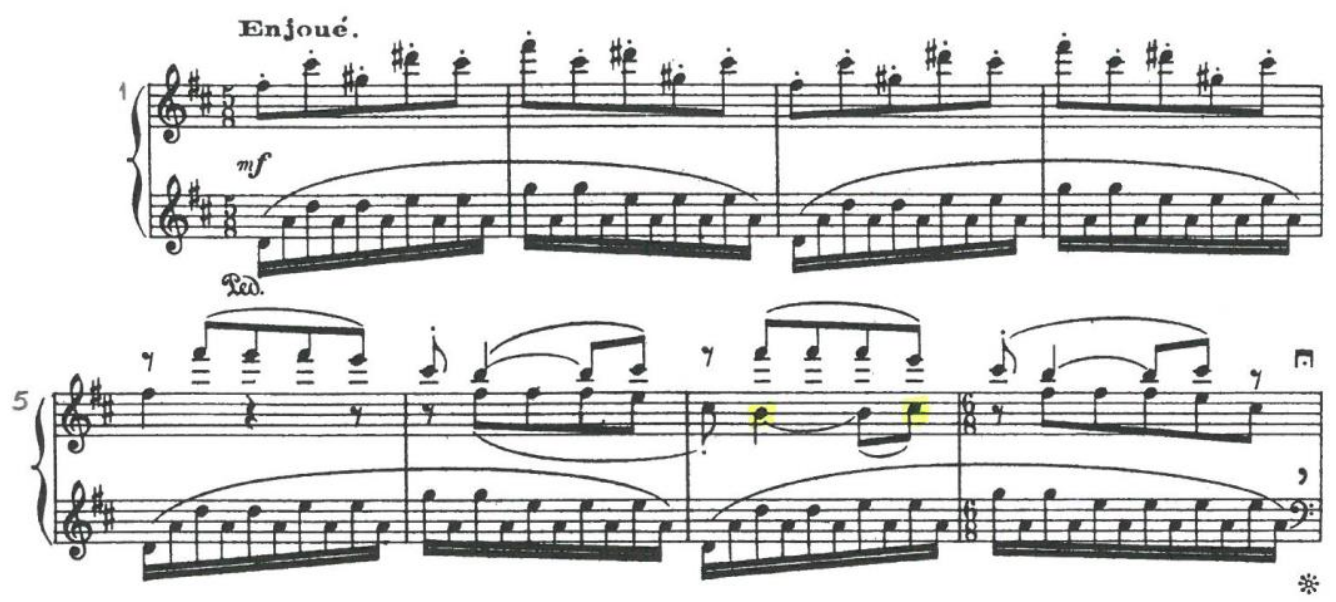

Figure 27. Tailleferre: Pastorale, Section I, mm. 1-8.

Section II has a tuneful and folklike melody in the right hand, which evokes a serene pastoral feeling, accompanied by a drone bass, $\mathrm{D} \#$ over $\mathrm{G} \#$, in the left hand. The soprano melody has a remarkably narrow range, the interval of fourth, in the first phrase (mm. 9-12). The ostinato in the alto voice is best played by the right-hand thumb on both the F\# and G\#. The first phrase 
(mm. 9-12) strongly suggests a tonal center of G\# minor. The second phrase (mm. 13-16) drops a half-step to $\mathrm{G}$ major in the left hand while retaining the similar scalar notes in the right hand. This conflict of $\mathrm{G}$ major harmony with $\mathrm{G} \#$ minor melody creates a spicy and colorful effect. Pianists with smaller hand span may need to roll the chords encompassing a $10^{\text {th }}$ and a $9^{\text {th }}$ in $\mathrm{mm}$. 13 and 14. In such case, place the top note on the beat but be certain to hold the bass note in the pedal.

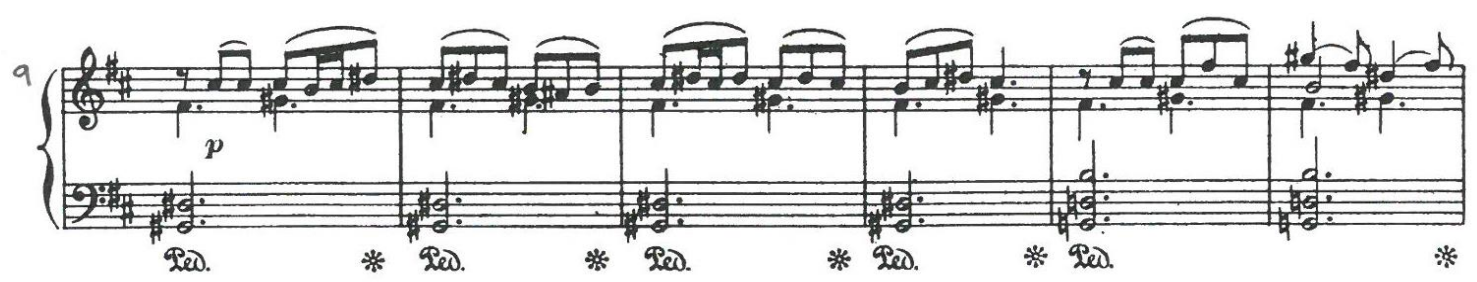

Figure 28. Tailleferre: Pastorale, Section II excerpt.

Section III demonstrates a textural similarity to the opening section with its broken-chord accompaniment and the same rhythmic concept of eighth and sixteenth notes in each hand respectively. ${ }^{52}$ However, it does not share the melodic ideas of the previous sections. It starts with a four-bar melodic phrase (mm. 17-20). The concluding motif, B-A-G\#-F\#, of this phrase (mm. 19-20) is echoed four times, first with its dissolving of melody, then with increased intensity and agitation through harmonization in thirds and triads (see Figure 29). This section leads to the climactic and loudest point of the piece in $\mathrm{m} .25$. Each hand suggests its own tonality, E and F Major, respectively. The transition from $5 / 8$ to $6 / 8$ at m. 20 is unanticipated. Emphasize the downbeat slightly to highlight this change. The section concludes quietly and

\footnotetext{
52 Left hand accompaniment in sections is either broken chord (I and III) or ostinato with the perfect fifth (II and IV).
} 
emphasizes the tonal center of E, lilting on B and E notes (mm. 27-28). This provides an opportunity for careful control of dynamics, since the E should be gentler than the B.

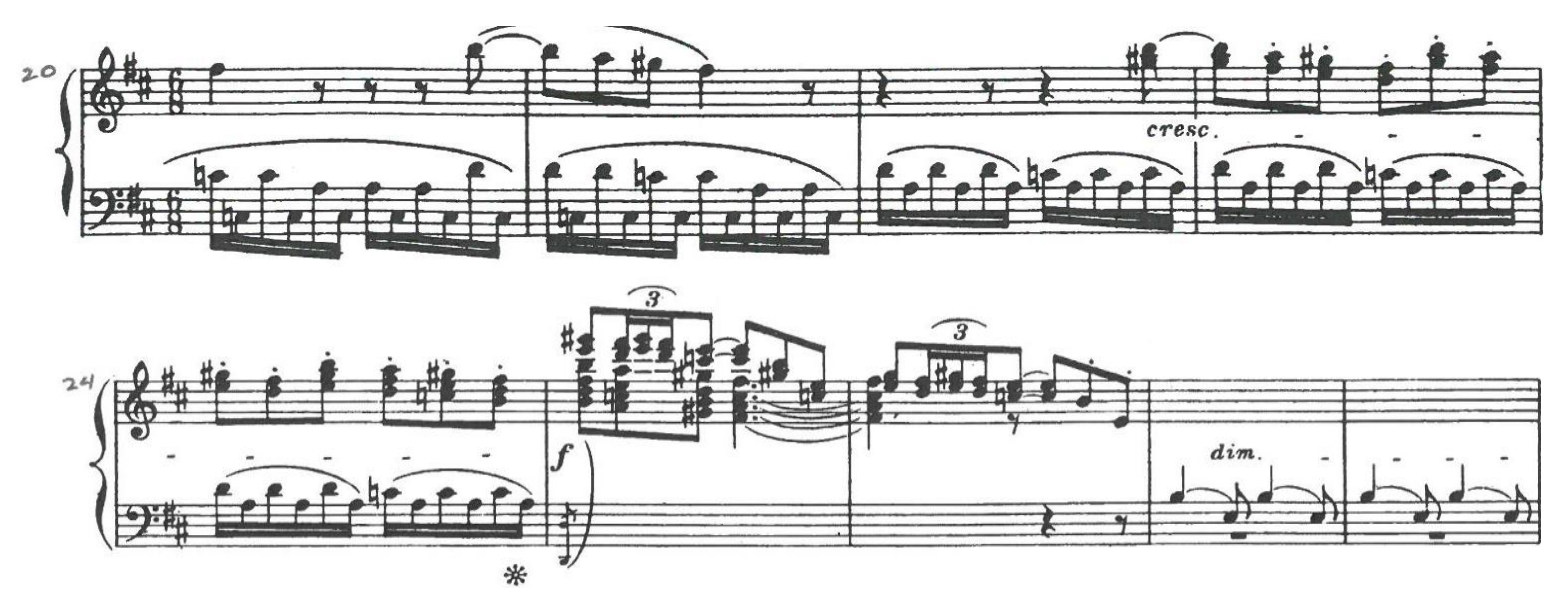

Figure 29. Tailleferre: Pastorale, Section III excerpt.

This lilt prepares for the tuneful melodic contour in section IV, recalling the similar pastoral mood of section II. Its strong E-major tonality, anchored by pedal point in the top of the texture and expressed through a melody that includes all the notes of an E-major scale except the leading tone - that is, a Guidonian hexachord on E - is blurred by the pedal point of fifth over D in the bass, combining the tonal areas introduced in sections I and III. This section incorporates the cross-hand technique for melody, bass, and syncopated chord - the last two by the left hand. The best execution is to play left hand under right. This arrangement allows to bring out the melody in tenor voice effortlessly. This section ends on the three dry B notes and a caesura.

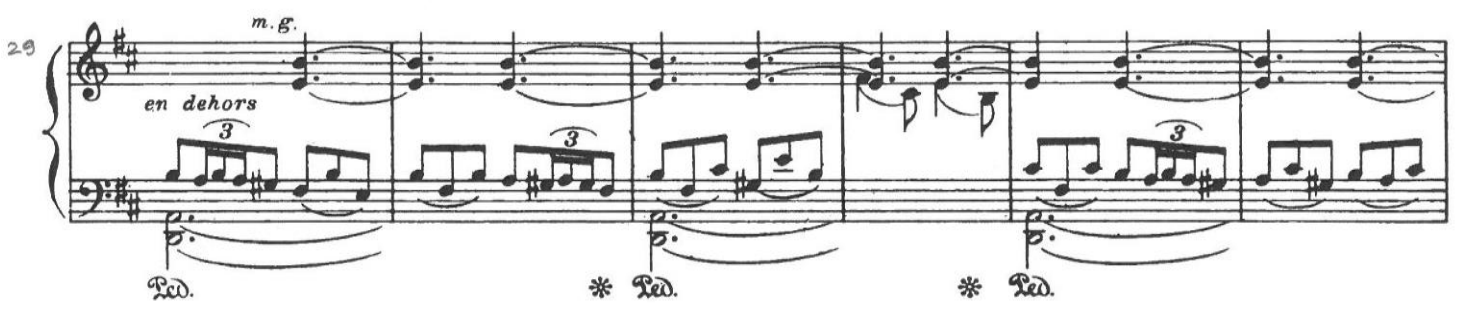

Figure 30. Tailleferre: Pastorale, Section IV excerpt. 
Section V suggests the tonal center of D with the chordal texture. The first phrase (mm. 37-40) incorporates all the notes of the D major scale except the leading tone - that is, another Guidonian hexachord. The right hand provides the melodic and accompanying lines in ostinato, alternating between $\mathrm{B}$ and $\mathrm{A}$ notes, and the fifths over $\mathrm{E}$ and $\mathrm{D}$ respectively, recalling the combination of $\mathrm{D}$ and $\mathrm{E}$ earlier. It also recalls the very narrow range of section II. The second phrase (mm. 41-44) retains the right-hand passages but changes the harmony to $\mathrm{Bb} 7$ with added $\mathrm{G}$ and missing F notes. Emphasize this harmonic change slightly in $\mathrm{m} .41$ to distinguish from previous phrase (mm. 37-40).

This section becomes gradually quieter and slower leading to the coda, Figure 31, which consists of five measures of a harmony, whose tonality leans towards D major. The accidentals,

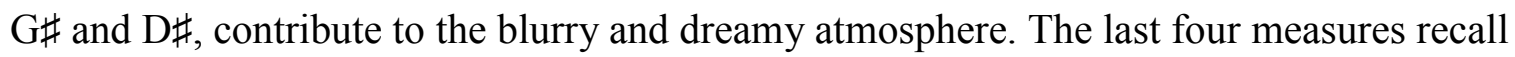
section I, the right hand notes: $\mathrm{F} \#, \mathrm{C} \#, \mathrm{G} \#$ and $\mathrm{D} \#$. Three (C\#, G\# and $\mathrm{D} \#)$ of them can easily serve as leading tones to all bass notes: D, A and E. Pastorale ends with the black-key/white-key bitonal concept of the opening.

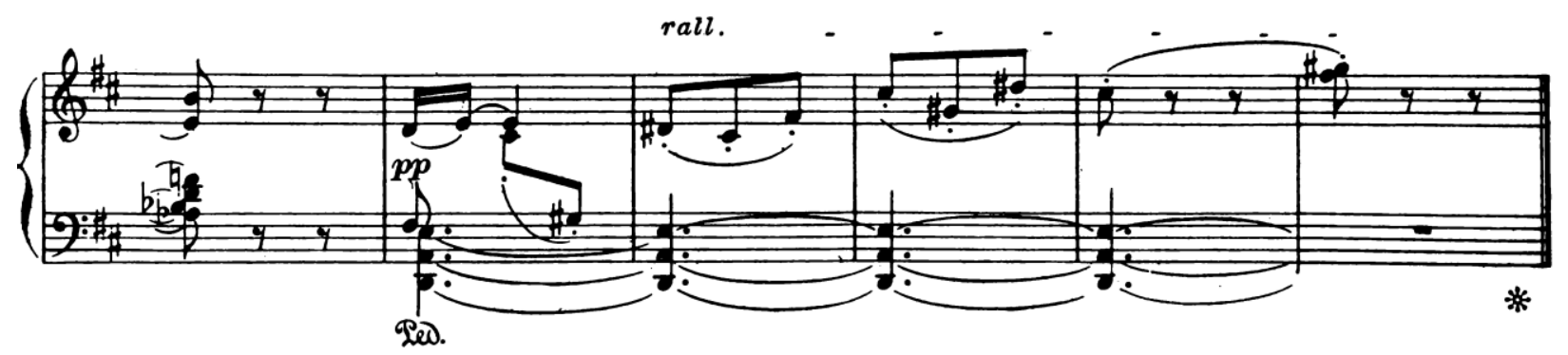

Figure 31. Tailleferre: Pastorale, mm. 48-53.

Tailleferre is generous with pedal markings. Her extensive pedaling, sometimes covering the entire section such as section I (mm. 1-8), evokes a blurry atmosphere effectively. However, it should be recognized that following her indications in a literalistic manner would lead to the muddiness. Therefore, a careful approach is indicated: just a half pedal, or shallow pedaling, 
would appropriately bring out the tuneful melody prominently over the blurred harmony. By contrast, the climactic point, mm. 25-26, does not have a pedal marking. Nevertheless, the passage requires pedaling to play the big chords smoothly. Change pedal at each beat to add warmth to the chords. In section V, follow her pedaling strictly to bring out the rests. In mm. 4144, start getting softer and slower. The tempo should be considerably slower in mm 45-47. Use full pedal to bring out the blurred harmony to project laissez vibrer. Release the pedal at the end of m. 47 while holding Ab, Bb, D, E. F and B for one eighth beat in m. 48 .

Tailleferre's Pastorale not only includes bitonality, but also incorporates contrasting articulations occurring at the same time, such as in mm. 1-4, 17-19, and 23-24. Here, the right hand plays a staccato motif over a molto-legato accompaniment in the left hand. Play the staccato motif short with bouncy hand; make accompaniment smooth and connected; and add dynamic inflections and pedal, creating a pointed sound rather than a true staccato.

This pianistic work is short yet sophisticated. It offers great variety in its two pages. Frequent meter changes, ambiguous tonalities and harmonies, sonorous sound, and narrow but tuneful melodic lines are some of its highlights. 


\section{$\underline{\text { Chapter Four - Conclusion }}$}

The primary motivations for the formation of Les Six in 1920 was the reaction in France against German Romantic music, especially of Richard Wagner, and to some extent, certain styles frequently associated with Debussy and Ravel with their light, delicate, evocative, and colorful characteristics. The chief architects of this movement were Erik Satie and Jean Cocteau. They developed a new French musical aesthetic: simplicity, directness, clarity, and terseness. Les Six followed these ideals in their formative years. Their artistic association was short-lived, but while it lasted it produced Album des Six, their sole joint production, a published six-piece piano set in 1920 . The works in the Album were primarily composed as independent pieces between 1914 and 1920, and were deliberately assembled to symbolize Les Six as a coherent group in 1920. However, the group was never cohesive. Durey's refusal to contribute music for Cocteau's 1921 ballet, Les mariés de la tour Eiffel, began the disintegration of their association. Poulenc said about their divergent paths:

We had never had any common aesthetic and our musical styles have always been dissimilar. Our likes and dislikes were opposed. Thus, Honegger has never liked Satie's music, and [Florent] Schmitt, whom he then admired, was a pet aversion for Milhaud and me. ${ }^{53}$

Despite this assertion, the Album incorporates the Satie-Cocteau aesthetics precisely; chiefly, the simplicity, clarity, economy, and the incorporation of neoclassicism. Satie's “Gymnopédie" provides a foundational model for the Album. The works include lyrical, expressive and tuneful melodies, which consistently determine the tonality. The melodies are mostly simple and folklike, influenced by the music hall and the café, except for the angular and

\footnotetext{
53 Poulenc, Francis. My Friends and Myself: Conversations [with] Francis Poulenc. Compiled by Audel, Stephane. Translated by James Harding. London: D. Dobson, 1978, 42.
} 
chromatic melodies of Honegger and Milhaud. The textures mostly consist of melody and accompaniment with the occasional additional line in the middle. The accompaniment provides non-functional, parallel and extended chords, which often avoid conforming to the melody, creating harmonic ambiguity. The works predominantly integrate sectional design. Sections are distinctive with their clear tonal centers and meters. The pieces generally incorporate balanced phrase structures of a two-measure unit and its multiplication. All these underlying elements emphasize the principal role of the melody in the Album and align with Cocteau's vision:

In music, line is melody. The return to design will necessarily involve a return to melody. The profound originality of a Satie provides young musicians with a teaching that does not imply the desertion of their own originality. Wagner, Stravinsky, and even Debussy are first rate octopuses. Whoever goes near them is sore put to it to escape from their tentacles; Satie leaves a clear road open upon which everyone is free to leave his own imprint. $^{54}$

Album des Six incorporates neoclassicism broadly as a "return" to the earlier principle and includes all three preceding centuries. Auric's Prélude anticipates the reoccurring elements of the set and serves as an ideal opener. These features include (as already stated) tuneful melody, balanced phrase structure, sectional design, bitonality and tonal ambiguity. Honegger incorporates linear writing in Sarabande with considerable chromaticism and provides the most contrasting texture in the set. The Renaissance influence is demonstrated by the use of modality including parallel dyads in "Romance sans Paroles," drone bass pedal points in Pastorale and Lydian mode in "Valse in C." The $19^{\text {th }}$ century romanticism is depicted in the descriptive pieces of Durey and Tailleferre.

Humor is an integral part of Album des Six, whose reference is both subtle and pronounced, again drawing its association with Satie. While the humor in Milhaud and Durey is

\footnotetext{
${ }^{54}$ Cocteau, Jean, Rollo H Myers, and Pablo Picasso. Cock and Harlequin : Notes Concerning Music. London: Egoist Press, 1921, 20.
} 
subdued, Poulenc and Auric offer it distinctly. Milhaud's inclusion of the Mazurka title arguably draws comparison with Satie's Embryons desseches, especially its satiric reference to a Mazurka by Schubert. Milhaud's work does not show any characteristic traits of the Mazurka rhythm, such as a strong accent on beat two, or three, or both. Milhaud's work is simply a melancholic piece in triple meter. Furthermore, Milhaud's work is published in a wrong ["common"] meter without any textural explanation: possibly another joke, although it seems more likely to be a print error. Similarly, Durey consistently used dissonant minor seconds to clash with the otherwise extremely tuneful and tonal melody in "Romance sans Paroles." The first return of the partial opening theme offers more obvious intervallic clash due to its extremely narrow range of melody and accompaniment.

Poulenc's Valse is primarily built on triadic and diatonic notes over a tonic and dominant harmony with occasional interruption by syncopated "wrong" notes. This interruption not only disrupts the triple-meter flow, but also creates amusing effects in this otherwise monotonous and mechanical piece. Likewise, Auric builds the opening rudimentary theme almost entirely with the tonic triad in Prélude, but the clear thematic tonality is blurred by the harmonic dissonant notes, creating a tonal ambiguity. The return of the opening theme incorporates black-key/whitekey bitonality, creating not only a stimulating sonority, but also offering interesting visual effect, each hand using respective black or white register. Prélude ends on a lively and upbeat spirit with both hands playing dry $3^{\text {rd }}$ in the extremes of the piano register. In contrast to Auric, Tailleferre integrates black-key/white-key bitonality to paint a pastoral and serene picture. Thus, the same pianistic approach is used for both seriousness and humor.

Album des Six includes a diverse set of pianistic pieces from a crucial period. Its musical elements represent the time and offer great material for the teaching studio as early twentieth- 
century French piano repertoire. This rarely performed 12-minute set is also an effective set to balance a program of standard repertoire on concert stage. Thus, Album des Six is an unexplored and era-defining pianistic gem for both a teaching studio and the concert hall. 


\section{Bibliography:}

\section{Books:}

Abraham, Gerald. A Hundred Years of Music. $3^{\text {rd }}$ ed. Chicago: Aldine, 1964.

Antokoletz, Elliott. Twentieth-Century Music. Englewood Cliffs, N.J.: Prentice Hall, 1992.

Brody, Elaine. Paris: The Musical Kaleidoscope 1870-1925. New York: George Braziller, 1987.

Cooper, Martin. French Music; from the Death of Berlioz to the Death of Fauré. London: Oxford University Press, 1969.

Demuth, Norman. French Piano Music: A Survey with Notes on Its Performance. London: Museum Press, 1959.

Gibb, James. "The Growth of National Schools.” In Keyboard Music. Denis Matthews, ed. New York: Praeger, 1972.

Gillespie, John. Five Centuries of Keyboard Music: An Historical Survey of Music for Harpsichord and Piano. California: Wadsworth, 1965.

Gordon, Stewart. A History of Keyboard Literature: Music for the Piano and Its Forerunners. New York: Schirmer, 1996.

Harding, James. The Ox on the Roof: Scenes from the Musical Life in Paris in the Twenties. New York: St. Martin's, 1972.

Hartog, Howard, ed. European Music in the Twentieth Century. New York: Praeger, 1957.

Honegger, Arthur. I Am a Composer. Translated by Clough \& Clough. New York: St. Martin's, 1966.

Kirby, F. E. A Short History of Keyboard Music. New York: Free Press, 1966.

Milhaud, Darius. Notes Without Music: An Autobiography. Da Capo Press Music Reprint Series New York: Da Capo, 1970.

Myers, Rollo H. Erik Satie. New York: Dover, 1968. . Modern French Music: From Fauré to Boulez. New York: Praeger, 1971.

Poulenc, Francis. My Friends and Myself: Conversations [with] Francis Poulenc. Compiled by Stephane Audel. Translated by James Harding. London: D. Dobson, 1978. 
Salzman, Eric. Twentieth-Century Music: An Introduction. 2nd ed. Englewood Cliffs, N.J.: Prentice-Hall, 1974.

Shattuck, Roger. The Banquet Years: The Arts in France, 1885-1918: Alfred Jarry, Henri Rousseau, Erik Satie, Guillaume Apollinaire. Garden City, New York: Anchor, 1961.

Slonimsky, Nicolas. Music Since 1900. 5th ed. New York: Schirmer, 1994.

Spratt, Geoffrey K. The Music of Arthur Honegger. Cork, Ireland: Cork University Press, 1987.

\section{Score:}

Les Six. Album des 6. Paris: E Demets, 1920.

\section{Articles:}

Chimènes, Myriam, and Roger Nichols. 2001 "Poulenc, Francis." Grove Music Online. 5 Apr. 2019. http:////www.oxfordmusiconline.com/grovemusic/view/10.1093/gmo/9781561592630.00 1.0001/omo-9781561592630-e-0000022202.

Drake, Jeremy. 2001 "Auric, Georges." Grove Music Online. 5 Apr. 2019. http:////www.oxfordmusiconline.com/grovemusic/view/10.1093/gmo/9781561592630.00 1.0001/omo-9781561592630-e-0000001539.

Drake, Jeremy. 2001 "Milhaud, Darius." Grove Music Online. 5 Apr. 2019. http:////www.oxfordmusiconline.com/grovemusic/view/10.1093/gmo/9781561592630.00 $\underline{1.0001 / o m o-9781561592630-e-0000018674 . ~}$

Griffiths, Paul. 2001 "Cocteau, (Clément Eugène) Jean." Grove Music Online. 5 Apr. 2019. http:////www.oxfordmusiconline.com/grovemusic/view/10.1093/gmo/9781561592630.00 1.0001/omo-9781561592630-e-0000006031.

Harbec, Jacinthe, and Nicole Paiement. 2001 "Collet, Henri." Grove Music Online. 5 Oct. 2018. http:////www.oxfordmusiconline.com/grovemusic/view/10.1093/gmo/9781561592630.00 1.0001/omo-9781561592630-e-0000006119.

Orledge, Robert. 2001 "Tailleferre, Germaine." Grove Music Online. 5 Oct. 2018. http:////www.oxfordmusiconline.com/grovemusic/view/10.1093/gmo/9781561592630.00 1.0001/omo-9781561592630-e-0000027390.

Rašín, Vera. "'Les Six" and Jean Cocteau." Music \& Letters 38, no. 2 (1957): 164-69. 
Robert, Frédéric. 2001 "Durey, Louis." Grove Music Online. 5 Oct. 2018. http:////www.oxfordmusiconline.com/grovemusic/view/10.1093/gmo/9781561592630.00 1.0001/omo-9781561592630-e-0000008391.

Spratt, Geoffrey K. 2001 "Honegger, Arthur." Grove Music Online. 5 Oct. 2018. http:////www.oxfordmusiconline.com/grovemusic/view/10.1093/gmo/9781561592630.00 1.0001/omo-9781561592630-e-0000013298.

\section{Dissertations:}

Gelfand, Janelle Magnuson. "Germaine Tailleferre (1892-1983): Piano and Chamber Works." Order No. 9936029, University of Cincinnati, 1999. https://search.proquest.com/docview/304498230.

Nelson, Jon Ray. "THE PIANO MUSIC OF FRANCIS POULENC." Order No. 7820754, University of Washington, 1978. https://search.proquest.com/docview/288282652.

Scheidker, Barbara Eileen. "Cultural Influences on the Piano Music of "Les Six"." Order No. 9617399, The University of Texas at Austin, 1995. https://search.proquest.com/docview/304228400.

Sitton, Michael Randy. "The "Album Des Six" and Pianism in the Works of Les Six, 1917--1925." Order No. 9124490, University of Illinois at Urbana-Champaign, 1991. https://search.proquest.com/docview/303941681. 